\title{
A presença das religiões afro-brasileiras em Maringá - PR (Século XXI)
}

\section{Resumo}

A fim de contribuir para a História das Religiões e Religiosidades e seu estudo das crenças, o foco desta pesquisa consiste em analisar e compreender o espaço e o papel das religiões afro-brasileiras em Maringá-PR, na atualidade. Por meio de um mapeamento geográfico e de visitas de campo para produzi-lo, apresenta-se a identificação das primeiras manifestações de mediunidade, da iniciação das lideranças religiosas e as relações formadas entre elas. Processo que procura evidenciar a presença dessas religiões na cidade a par de estratégias públicas etnocêntricas de apagamento do papel da cultura afro-brasileira na sociedade. Por fim, evidencia-se a presença física e histórica das religiões afro-brasileiras na cidade de Maringá. O espaço da memória foi pensado enquanto meio de priorizar determinados aspectos do passado na arquitetura urbana (TUAN, 1983; ROSENDAHL, 1999; 2008).

Palavras-chave: Maringá. Religião afro-brasileira. Memória.

\author{
Vanda Fortuna Serafim \\ Doutora em História pela Universidade \\ Federal de Santa Catarina (UFSC). Professora \\ do Programa de Pós-Graduação em História \\ da Universidade Estadual de Maringá (UEM). \\ Maringa, PR - BRASIL \\ vandaserafim@gmail.com \\ orcid.org/0000-0001-7707-7792
}

\section{Giovane Marrafon Gonzaga}

Doutorando em História pelo Programa de Pós-Graduação em História da Universidade Estadual de Maringá (UEM). Maringa, PR - BRASIL

giovanemg@gmail.com orcid.org/0000-0002-7030-7468

\section{Para citar este artigo:}

SERAFIM, Vanda Fortuna; GONZAGA, Giovane Marrafon. A presença das religiões afrobrasileiras em Maringá - PR (Século XXI). Tempo e Argumento, Florianópolis, v. 11, n. 28, p. $320-364$, set./dez. 2019. 


\title{
The presence of afro-brazilian religions in Maringá - PR - BRAZIL (XXI Century)
}

\begin{abstract}
To contribute to History of Religions and Religiosities and the studies of beliefs, the focus of this research consists analyzing and comprehending the space and the role of Afro-Brazilians religions in Maringá-PR, nowadays. The geographical mapping, and the field research to produce that, gave the opportunity to identify of the first manifestations of mediumship, of the initiation of religious leaderships and the relation created between them. A process that seeks to evidence the presence of these religions in the city instead of public ethnocentric strategies aimed at erasing the role of Afro-Brazilian culture in society.Finally, it was evidenced the physical and historical presence of Afro-Brazilians religions in the city of Maringá. The space of memory was thought how the mean to prioritize determined aspects of the past in the urban architecture. (TUAN, 1983; ROSENDAHL, 1999; 2008).
\end{abstract}

Keywords: Maringá. Afro-Brazilians Religions. Memory.

O presente artigo apresenta parte dos resultados alcançados em nossa pesquisa institucional sobre as religiões afro-brasileiras em Maringá, no período de 2012 a 2018, vinculada ao Departamento de História e Programa de Pós-Graduação em História da Universidade Estadual de Maringá, com financiamentos parciais da Capes e Fundação Araucária. A pesquisa teve três grandes frentes: produção bibliográfica sobre a cidade, periódicos e pesquisa de campo/questionários.

No primeiro momento analisou-se a escrita memorialista sobre a história do município1. Para pensar a presença das crenças afro-brasileiras na cidade de Maringá, torna-se necessário destacar os processos de produção da memória coletiva da e sobre a cidade. Denominamos escritos memorialistas, obras que contribuíram para a associação da cidade a uma tradição católica, geralmente carregadas de marcas do discurso dos

\footnotetext{
1 Por meio das obras de Jorge Ferreira Duque Estrada (2014 [1961]), Rubens Rodrigues (1975), Arthur Andrade (1979), Osvaldo Reis (2004) e Orivaldo Robles (2007).
} 
pioneiros da cidade e que em grande parte silenciam a presença da população negra nesta região. No segundo momento, trabalhou-se com fontes periódicas por meio do jornal O Diário, principal veículo de informação impresso da cidade, com quase quatro décadas de circulação. De maneira geral, evidenciaram-se alguns aspectos recorrentes a respeito das religiões afro-brasileiras: a utilização de termos evolucionistas; a crença de que seus ritos religiosos visem o malefício; a relação das crenças afro-brasileiras à capacidade da vidência. Há, no entanto, matérias, especialmente no século XXI, que apresentam as lideranças religiosas, seus templos e seus preceitos, assumindo um esforço de alteridade. No terceiro momento, estudou-se a presença das religiões afrobrasileiras em Maringá, com base em visitas de campo realizadas em 37 locais de prática religiosa afro-brasileira e aplicação de questionários, com o intuito de conceber como essas práticas, de fato, se organizam na cidade, ao invés de enquadrá-las em noções gerais de outras épocas e localidades.

Para a finalidade deste artigo, optamos por apresentar os resultados deste último momento da pesquisa, acima indicado. Certamente, as três frentes são essenciais para a compreensão mais abrangente da história da cidade, da presença das populações negras e de suas práticas culturais e religiosas e dos embates na construção da memória da cidade; ainda assim, há a necessidade de um recorte que viabilize a apresentação em formato de artigo ${ }^{2}$. Portanto, o objetivo aqui consiste em discutir a presença das religiões afro-brasileiras em Maringá-PR, no século XXI, tomando como base documental as pesquisas de campo/questionários criadas como resultado das visitas de campo realizadas em 37 locais na cidade.

É importante ressaltar que no campo da historiografia, esse é primeiro trabalho que visa mapear e discutir as religiões afro-brasileiras em Maringá, município brasileiro do estado do Paraná, sendo uma cidade média-grande planejada e de urbanização recente, a terceira maior cidade do estado e a sétima mais populosa da região sul do Brasil. De acordo com o Instituto Brasileiro de Geografia e Estatística (IBGE), Maringá possuía em 2017, uma população de 406.693 habitantes e sua Região Metropolitana conta com

\footnotetext{
2 Para ter acesso aos demais resultados da pesquisa, vide: GONZAGA, Giovane Marrafon. Memórias, notícias e espaços: a presença das religiões afro-brasileiras em Maringá-PR (2000 - 2014). Dissertação (mestrado em História) - Universidade Estadual de Maringá, Maringá, 2018, p.158.
} 
754.570 habitantes (IBGE/2015). Maringá vem sendo historicamente pensada como um espaço católico, tanto pelos escritos memorialistas, como pela historiografia que privilegiou tratar aspectos das crenças católicas em suas abordagens (GONZAGA, 2018).

Havia, então, uma grande lacuna histórica, como indica o artigo de Amorim (2009) com um título já bastante sugestivo "Religiões Afro-brasileiras na Região de Maringá: Diversidade e Invisibilidade". Amorim explicava que as pesquisas apontavam a quantidade e diversidade de manifestações religiosas, indicando que a aparente invisibilidade de cerca de 50 templos das religiões afro-brasileiras e sua inserção na região de Maringá mereciam uma investigação mais detalhada (AMORIM, 2009). A partir do levantamento quantitativo, observação participante e utilização de questionários junto aos templos em Maringá, Sarandi, Marialva e Mandaguari, tal pesquisa constatou que, na maioria dos casos, os templos situavam-se em bairros periféricos, e que alguns já se localizaram em áreas mais centrais ou no município maior, mas por pressão dos outros grupos, com diferentes orientações religiosas, foram “empurrados” para municípios limítrofes, na região metropolitana. A caracterização dos templos é bem diversificada, com predomínio da Umbanda como característica geral dos cultos. Entretanto, há significativa presença de outras designações religiosas, como o Candomblé, o Omolokô e o Tambor de Mina³, esses dois últimos chegaram a Maringá na última década (AMORIM, 2009)

A princípio, o curto artigo da antropóloga Amorim (2009), era o único material disponível sobre as religiões afro-brasileiras em Maringá. Mais recentemente, houve a defesa da tese de doutorado, do sociólogo Eronildo José da Silva (2014) “Maringá de todos os santos: presença das religiões afro-brasileiras". Sua pesquisa objetivou, a partir da observação da negação da presença negra em Maringá, revelar tal presença por meio de suas expressões religiosas. Ao destacar que o universo religioso afro-brasileiro em Maringá ainda seria desconhecido pela maioria, Silva mapeou os terreiros atuantes na cidade, suas origens, filiações (linhagens), seus sacerdotes e adeptos e, como encaram o preconceito e as relações entre os terreiros e a sociedade (SILVA, 2014).

\footnotetext{
${ }^{3}$ Ao leitor que queira se familiarizar com as especificidades de cada denominação, sugerimos a leitura de $A$ experiência dos orixás (1997) de Berkenbrock, em que o autor traz, sistematizados, esses significados, mas também de outros termos fundamentais à compreensão das religiões afro-brasileiras.
} 
Em nossa interpretação, o autor defende que o caso das religiões afro-brasileiras e o que caracteriza enquanto processo de 'invisibilidade' (termo adotado pelo autor) é demonstrativo de um aspecto geral do apagamento público da população negra maringaense. No entanto, isso não significa que a religião de tal parcela se limite à prática religiosa afro-brasileira. Pelo contrário, se tomássemos apenas o censo de 2010 do IBGE, em que apenas 11 das pessoas declaradas da cor preta afirmaram participar da Umbanda ou Candomblé, enquanto católicos contam 6.730 pessoas e evangélicos, 3.729.

Reginaldo Prandi (2003), em “As religiões afro-brasileiras e seus seguidores", procura destacar fatores que contribuem para considerarmos problemáticos os dados do IBGE sobre a população negra e as religiões afro-brasileiras. De um passado nacional, o autor salienta que mesmo praticantes de outras religiões preferiam se autodeclarar católicos, primeiro porque, durante muito tempo na história do Brasil, o catolicismo foi a única religião permitida por lei. Segundo, a virada do último século demonstrou um grande crescimento das religiões pentecostais, expansão que aparentemente se mantém na atualidade. O pentecostalismo, para Prandi, se solidificou a partir de um passado de perseguição e humilhação das religiões afro-brasileiras, com cultos e programas televisivos trazendo supostos médiuns incorporados para depois exorcizá-los. A crescente do pentecostalismo e sua campanha agressiva amealhariam adeptos da Umbanda e do Candomblé. Ao mesmo tempo em que a tese de Silva (2014) tornou-se fundamental para minha pesquisa, me afastei de algumas premissas do autor, na medida em que não trabalhei apenas com a noção de "terreiro", termo que se refere aos templos e edificações em torno das quais se realizam cultos afro-brasileiros ${ }^{4}$, tais como a Umbanda e Candomblé. Operacionalizo o conceito de "crença", ao modo de Michel de Certeau (1998), por entender que a crença nos permite asseverar que a enunciação religiosa é a inscrição da experiência vivida numa linguagem, que possibilita a atuação sobre a alteridade de sentido e leva à ação aquele que crê, ou seja, “[...] entendo por 'crença' não o objeto do crer (um dogma, um programa etc.), mas o investimento das pessoas em uma proposição, o ato de enunciá-la considerando-a verdadeira - noutros termos, uma ‘modalidade’ da afirmação e não seu conteúdo” (CERTEAU, 1998, p. 278).

\footnotetext{
${ }^{4}$ Mesmo entre as religiões citadas, não é unanimidade a adoção do termo terreiro para se referir aos templos. Como demonstra Conduru (2010), o termo "roça" é bastante utilizado entre fiéis do Candomblé no Rio de Janeiro. Já entre os locais visitados durante a pesquisa, anotamos os termos "centro" e "tenda" como formas de se referir ao local religioso umbandista.
} 
Amorim (2009) e Silva (2014) utilizaram o termo 'invisibilidade' para descrever as religiões de matriz africana em Maringá. Certamente essas práticas não são invisíveis, uma vez que os próprios autores, e nossa pesquisa, corroboram a possibilidade de vê-las, mapeá-las e estudá-las. Como estratégia histórica, esses grupos religiosos assumem técnicas de camuflagem da crença, a fim de assegurar a própria sobrevivência, frente à intolerância tanto religiosa quanto racial. Nesse sentido, a noção de paradigma indiciário de Carlo Ginzburg (1990) foi fundamental para a metodologia da pesquisa: no sentido de refletir como trabalhar com as questões históricas negligenciadas, cuja existência se percebe em pistas infinitésimas da realidade, acerca das quais há apenas indícios.

A ideia de invisibilidade não se dá por acaso. De maneira geral, a produção memorialista ${ }^{5}$ valoriza as contribuições da Igreja na fundação da cidade. Como nota Gonçalves (1995), a partir da década de 60, os escritos produzidos sobre o passado maringaense obedecem a um critério de reengenharia da memória. Tal processo corresponde a uma versão do passado produzida a partir das relações entre elite-IgrejaCompanhia Melhoramentos. Para o autor, os interesses desse tripé engendram um perfil particular de migrante para ser morador da novíssima Maringá, fundada oficialmente em 1946. Tal perfil diz respeito a características culturais e étnicas específicas, como o catolicismo e a descendência europeia. Também, Fernandes (2014), assinala relações semelhantes quando trata do migrante nordestino no munícipio, descrevendo um cenário de perseguição e preconceito em relação a essas pessoas, ao qual retornaremos mais adiante.

A própria produção jornalística da cidade criou uma memória escrita acerca das religiões afro-brasileiras pautadas na ideia de exotismo, magia e vidência, tanto nas reportagens produzidas em outros locais e trazidas ao leitor maringaense, como nas próprias produções locais (GONZAGA, 2018). Partindo de tais referências documentais, por um lado notamos que a produção memorialista e o discurso público tornam invisível a participação das religiões afro-brasileiras. Por outro, a imprensa, por meio de indícios,

\footnotetext{
${ }^{5}$ Ao leitor que se interesse pela questão, no seguinte trabalho nos debruçamos a fundo sobre esse tema: GONZAGA, Giovane Marrafon. Memórias, notícias e espaços: a presença das religiões afro-brasileiras em Maringá-PR (2000 - 2014). Dissertação (mestrado em História) - Universidade Estadual de Maringá, Maringá, 2018, p.158.
} 
sinais distribuídos entre diversas edições, permite notar a crença, presença e atuação dessas religiões na cidade.

É preciso questionar essa memória consolidada sobre o município. Nesse sentido, gostaríamos de contribuir para maior percepção da presença dessas crenças em Maringá, destacando a necessidade de utilizar metodologias que aproximem, fisicamente, o pesquisador dessas manifestações; a pesquisa de campo e os estudos sobre a relação entre oralidade e história responderam satisfatoriamente tal intento.

No período de 2013 a 2016, visitei diversos locais de cultos afro-brasileiros na cidade. Por vezes existe o espaço de um terreiro, por vezes trata-se de uma residência onde um médium recebe entidades, joga cartas ou realiza benzimentos. Essas visitas foram importantes, pois a cada novo local que visitava, conseguia informações sobre outro lugar. No total, foram localizados 37 espaços que realizam práticas afro-brasileiras em Maringá.

A localização desses espaços teve como referência a lista de templos maringaenses elaborada por E. Silva (2014, p. 71-77). Dados de grande utilidade, principalmente por conterem o endereço desses espaços, facilitando seu encontro. Em alguns casos, as lideranças visitadas nos deram indicações de outros templos. Outros locais foram encontrados a partir da pesquisa nos classificados do jornal O Diário do Norte do Paraná, onde os anúncios de serviços religiosos nos trouxeram o telefone de contato de diversas lideranças. Por fim, o zelador-de-santo, Giancarlo Roger Hilário, além de permitir a ida a campo em seu próprio terreiro, abriu as portas de outros locais, nos apresentando pessoas e facilitando a pesquisa graças à sua boa reputação. Nas visitas por ele direcionadas, pudemos ouvir mais a respeito das relações entre os representantes de lideranças religiosas na cidade, fato pouco comentado quando íamos sozinhos a esses locais.

Ao encontrarmos esses endereços, o primeiro passo foi nos apresentarmos, dizer quais instituições representávamos (UEM e Laboratório de Estudos em Religiões e Religiosidades/LERR), informar o objetivo daquela visita, apresentar o questionário antes de executá-lo e pedir pela participação, da liderança, em nossa pesquisa. Embora atendêssemos a um roteiro de questões e abordagens, em muitos dos casos, essas 
articulações foram abandonadas privilegiando a cronologia do relato criada pelo próprio sujeito. Assim, ainda que todas as narrativas de campo apresentem uma trajetória descritiva semelhante, estas foram construídas após nossas visitas.

Noutro caso, não insistimos em obter certas informações quando visualizávamos possíveis constrangimentos. Por exemplo, uma liderança que, enquanto falava de parte de sua história de vida, comentava que havia se casado, mas nada dizia a respeito do marido. Ou quando não entrávamos no assunto do altar em nossas conversações, e era sentida uma timidez do representante em nos mostrar o mesmo. Nesses casos, preterimos tais dados ao invés de forçar o participante a apresentá-los, sempre respeitando as escolhas daqueles que nos recebiam e partilhavam suas trajetórias. Esses cuidados são descritos por S. Beaud e F. Weber (2007) sobre a produção e análise de dados etnográficos. Considerações que auxiliam na organização dos momentos anteriores à entrevista. A leitura de Bernard (2006), Alberti (2004) e Portelli (1996) contribuíram, respectivamente, para a organização dos cadernos de campo, de um roteiro de entrevista e na abordagem das pessoas envolvidas na pesquisa.

No décimo quarto capítulo de Research methods in anthropology, Bernard (2006, p. 389-395, tradução nossa) orienta a produção de anotações de campo a partir de quatro etapas: rascunho, diário, cronograma de eventos e caderno de campo. As anotações foram descritivas e circularam dois aspectos principais, o templo e seu espaço, e uma breve biografia da liderança religiosa. Alberti (2004) e Portelli (1996) contribuíram no sentido de problematizarem a relação entre oralidade e história, além de fornecerem certos instrumentos metodológicos caros ao momento da visita. A recomendação de um roteiro geral, por exemplo, possibilitou estruturar informações e temas importantes, como o período de estabelecimento na cidade, da relação entre lideranças religiosas e a relação entre o templo e a cidade. Os dados colhidos das visitas de campo foram produto do preenchimento de um questionário (anexo ao final do artigo), da observação e descrição dos templos e da conversa com sacerdotes. Sobre esse último aspecto, Portelli (1996) se tornou uma leitura determinante para o artigo ao entender que o diálogo com a fonte desenha um campo de possibilidades expressivas para a historiografia. 
Dessa forma, procuramos relacionar a narrativa das lideranças religiosas com a história de Maringá e das religiões afro-brasileiras nessa cidade e no Brasil. Este trabalho não pesquisa profundamente a biografia e dinâmica religiosa de cada uma das lideranças aqui constadas. Nosso objetivo foi de estabelecer contatos, averiguando um panorama geral das crenças afro-brasileiras em Maringá-PR e de como essas ocupam os espaços da cidade.

Ao produzirmos uma linha temporal, dividindo grupos em períodos de 20 anos desde a fundação da cidade, o fizemos com a intenção de comparar o momento dessas lideranças com contextos da cidade e do Brasil. Ao comentar sobre as relações com as lideranças religiosas da cidade, procuramos demonstrar que existem transformações, causadas pela forma como as crenças afro-brasileiras se organizam no município. As referências às primeiras manifestações mediúnicas têm a intenção de mostrar, por exemplo, que exigem esforços e responsabilidades que, muitas dessas pessoas, não encontram prazer em assumir. Não bastasse o peso a se carregar pelo papel de liderança religiosa, soma-se ainda o preconceito social que obriga aquele médium a sê-lo apenas do portão para dentro de sua residência.

O mapa tem o objetivo de ilustrar de que maneira as lideranças religiosas estão distribuídas em Maringá, o número de pessoas que a pesquisa contatou, a relação da distribuição espacial dos templos com o território da cidade. Pensando o passado brasileiro, etnocêntrico e de um cristianismo impositivo, notamos também a necessidade de cartografar esses locais de culto como forma de validar sua existência na história maringaense.

Uma das características que os locais de prática religiosa afro-brasileira em Maringá têm é o afastamento da região central6; apenas quatro se localizam a menos de 2 $\mathrm{km}$ do centro da cidade (números 6, 12, 20 e 29). Em uma paisagem desenhada entre as décadas de 1970 e 1980, quando a prefeitura procurou conter a 'favelização do município', que desde 1950 recebia um intenso movimento migratório:

\footnotetext{
${ }^{6}$ Delimitada ao Norte com a Avenida Colombo e a Universidade Estadual de Maringá. Ao Oeste, com a Avenida Mandacaru, Avenida Dezenove de Dezembro e Avenida Curitiba. Ao Sul, com a Avenida Tiradentes, Avenida São Paulo e Avenida Laguna. Ao Leste, com a Avenida Riachuelo até o trajeto de volta à Avenida Colombo.
} 
Essas ações de "limpeza na ordem urbana" tiveram início na administração de Sílvio Magalhães Barros (1973-1977), prosseguindo no segundo mandato do prefeito João Paulino Vieira Filho (1977-1982) e finalizando no mandato seguinte do prefeito Said Ferreira (1983-1988). Dessa forma, a intervenção do poder público previa a transferência das 14 favelas localizadas próximas ao cemitério da cidade para núcleos populares construídos com recursos públicos para justamente receber essas pessoas [...] (SHIMADA, 2015, p. 103)

Imagem 1. Distribuição geográfica das práticas religiosas afro-brasileiras em Maringá.

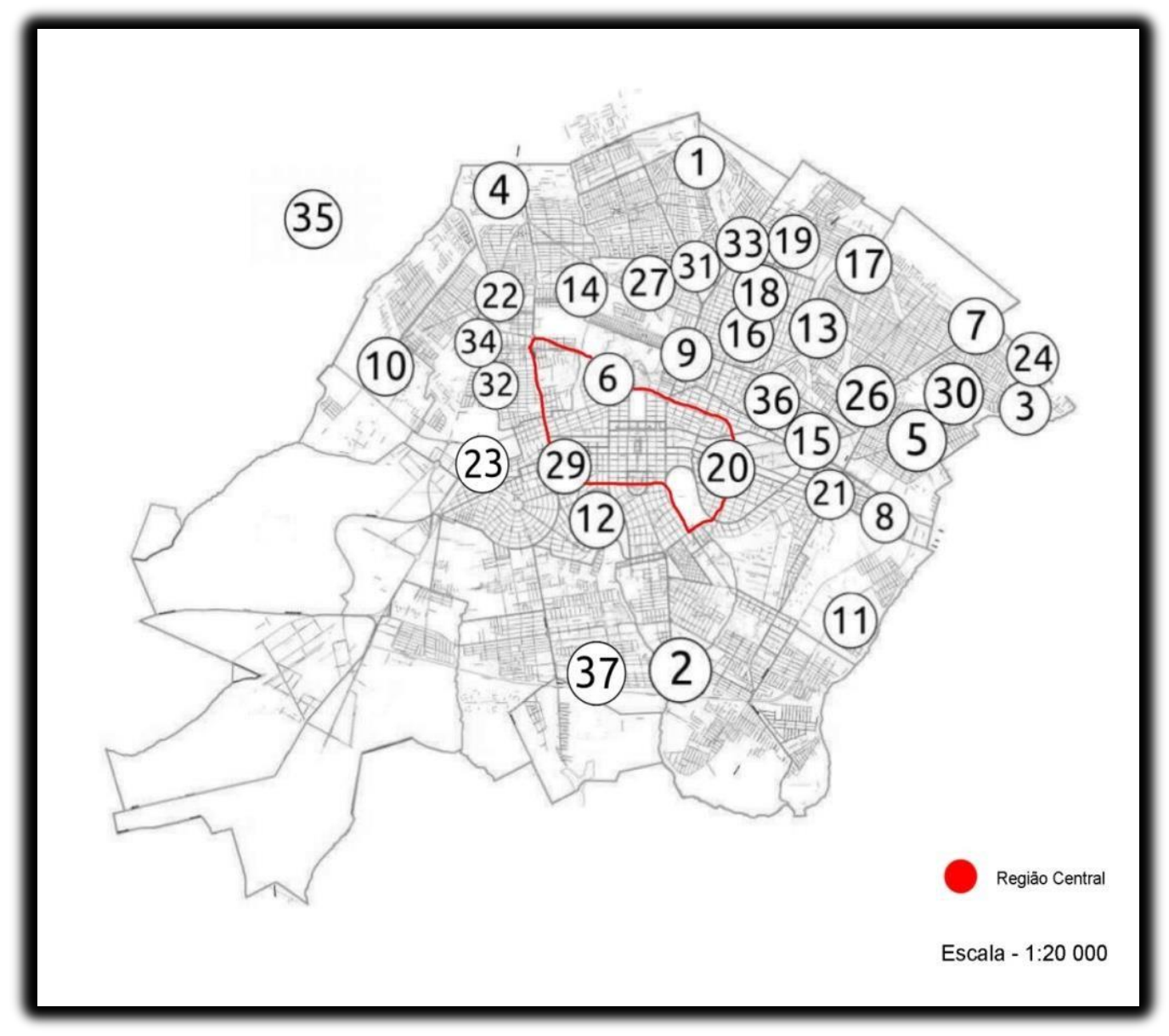

Fonte: Giovane M. Gonzaga, 2017.

Legenda:

1. Mãe Agnela; 2. Pai Agostinho; 3. Pai Armando; 4. Mãe Clô; 5. Dona Dirce; 6. Mãe Elisa; 7. Dona Fia; 8. Mãe Francisca; 9. Zelador Gian; 10. Glória Coutinho; 11. Mãe Glória; 12. Pai Hermano; 13. Mãe Joaninha; 14. Pai Jorge de Xangô; 15. Pai José; 16. Pai Josias; 17. Mãe Lourdes; 18. Mãe Luzia; 19. Mãe Marilza; 20. Mãe Mocagi; 21. Mãe Nerê; 22. Dona Onofra; 23. Seu Osmar; 24. Mestre Pedro; 25. Dona Rosiane; 26. Mãe Ruth; 27. Dona Sirene; 28. Dona Selma; 29. Terreiro Pai João da Mata; 30. Pai Zezinho; 31. Pai Beto de 
Desse remanejamento, surgiram bairros como o Conjunto Habitacional Santa Felicidade e a Vila Esperança (CORDOVIL, 2010). Foi também o período de maior fixação de pessoas no Jardim Alvorada, bairro planejado para a população carente da época, composto em sua maioria, por operários de fábrica e trabalhadores braçais. Foi nesse contexto que a maior parte dos terreiros, ainda atuantes na cidade, foi estabelecida.

Não estamos falando que, devido diretamente às políticas públicas da época, os terreiros foram removidos do centro de Maringá. Todavia, ao menos Mãe Clô (número 4) e Pai Zezinho (número 10), que possuíam seus templos na Vila Operária, região central, durante os anos 80, se mudaram para zonas limítrofes da cidade7. Aqueles que permaneceram, já não realizam giras semanalmente (Mãe Mocagi, número 20) ou realizam cerimônias sem a presença de tambores, o que faz chamar menos atenção. Não se trata, portanto, de uma necessidade de ficar próximo à natureza apenas, mas necessidade de preservar-se para não atrair a atenção pública, assegurando a integridade física e moral dos grupos que frequentam esses espaços.

A faixa que abrange, desde o terreiro de Mãe Nerê (número 8) até as antigas instalações de Mãe Neuza e Seu Álvaro (número 33), delimita parte das localidades, onde se situavam as favelas na cidade (SHIMADA, 2015). Apesar de não ser um indicativo do poder aquisitivo das lideranças aqui contempladas ${ }^{8}$, sugerem que, desde a fundação da cidade, os templos de religiosidade afro-brasileira têm se estabelecido nos limites da área urbana do município. Prova disso, é a localização dos últimos terreiros aqui estabelecidos (números 10, 11, 23, 25, 26, e 31).

A história de fundação desses templos, suas relações com a região em que estão inseridos e os movimentos dessas lideranças pela cidade, podem ser acompanhados por meio dos relatos contidos no Trabalho de Campo. Ao visitar os locais de prática religiosa

\footnotetext{
7 A ocupação do espaço urbano foi um dos temas estudados por Conduru (2010) em "Das casas às roças: as comunidades de candomblé no Rio de Janeiro", Em que o autor demonstra que o posicionamento periférico de muitos templos não diz respeito apenas a um processo de exclusão social. Embora este seja um ponto determinante para a arquitetura e dinâmica desses locais, a região periférica da cidade estaria mais próxima da natureza, das matas e rios que, por exemplo, são espaços de valor religioso e essenciais para condução de muitos ritos de matriz cultural africana.

8 Embora não tenhamos nos preocupado em obter dados sobre a renda das lideranças pesquisadas, a maioria dos locais é de propriedade dos seus ocupantes. Inclusive muitos foram reformados nos últimos anos, o que denota certa estabilidade econômica.
} 
afro-brasileira em Maringá, utilizou-se um modelo de questionário (Anexo 1) que, embora nem sempre seguido à risca, serviu como ponto de partida para o início da conversa. Passemos à análise dos dados obtidos no cruzamento entre um panorama de distribuição geográfica dos templos e as visitas com as lideranças religiosas que concordaram em participar da pesquisa.

\section{Lideranças religiosas em Maringá e o Tempo}

A fim de apresentar as lideranças visitadas e as informações obtidas por meio da pesquisa de campo, criou-se uma linha temporal, iniciando com os mais antigos de nossos colaboradores até os mais novos. Optamos por orientar a linha temporal por meio de tabelas que se referissem aos três períodos destacados de pais, mães-de-santo, benzedeiras e videntes, nomenclaturas que respeitam suas autodenominações.

Tabela 1. Primeiro Grupo de Lideranças Religiosas

\begin{tabular}{|l|}
\hline \multicolumn{1}{|c|}{ Décadas de 1940 a $1960^{9}$} \\
\hline Mãe Agnela \\
Pai Agostinho \\
Dona Fia \\
Pai Jorge de Xangô \\
Mãe Luzia \\
Mãe Mocagi \\
Mãe Nerê \\
Dona Onofra \\
Mãe Oscarina (já falecida) - mãe biológica de Mãe Marilza. \\
\hline
\end{tabular}

Fonte: Giovane M. Gonzaga, 2017.

As lideranças religiosas que representam esse grupo estão presentes desde os anos iniciais da povoação em Maringá. Entre os terreiros que coordenam suas atividades até hoje, é provável que o mais antigo deles seja o Terreiro de São Jorge, de Mãe Mocagi, iniciado em 1950. O mais novo é administrado por Pai Agostinho, fundado em meados dos anos de 1970, embora seu dirigente tenha sido iniciado em Maringá na primeira metade da década de 1950. Os locais de origens podem remeter ao município maringaense e 
região (Pai Jorge de Xangô, Mãe Luzia, Mãe Mocagi e Mãe Nerê) ou de cidades do estado da Bahia (Mãe Agnela, Pai Agostinho, Dona Fia). Dona Onofra, ainda que tenha nascido em Gimirim, Minas Gerais, teve praticamente toda sua gestação na cidade de Salvador, Bahia, de onde pais e familiares são oriundos.

Para cada grupo também foi produzida uma tabela com os responsáveis pela iniciação religiosa de determinada liderança. Noto que, nos casos em que não pude colher tal informação, o nome do sacerdote não aparece na tabela. As lideranças religiosas nascidas no município, ou para cá vindas na primeira infância, em sua maioria, tiveram seus ritos iniciáticos realizados na região de Maringá, como demonstra a Tabela 2:

Tabela 2. Responsáveis por iniciar as Lideranças do Primeiro Grupo

\begin{tabular}{|c|c|}
\hline Liderança religiosa & Responsável por sua iniciação \\
\hline Pai Agostinho & Caboclo Baltazar* \\
\hline Pai Jorge de Xangô & Mãe Luzia \\
\hline Mãe Luzia & Mãe Sandra* \\
\hline Mãe Mocagi & Joãozinho da Colméia - Rio de Janeiro \\
\hline Mãe Nerê & Dona Zilda* + Pai Jacó* \\
\hline
\end{tabular}

*Lideranças já falecidas. Fonte: Giovane M. Gonzaga, 2017.

A tabela acima reforça a possibilidade de que lideranças de religiosidade afrobrasileira já estavam locadas no período da fundação de Maringá. Chamo atenção para a história de Pai Agostinho que, durante os anos de 1950, teve sua iniciação realizada pelo Caboclo Baltazar, que provavelmente está entre os primeiros habitantes do Norte Novo do Paraná (excetuando a população indígena). O termo caboclo denominava a população descendente de escravos e nativo-americanos, que ocupava esse território entre os finais do século XIX e primeiras décadas do século XX (GONÇALVES, 1995).

Segundo Pai Agostinho (2017), seu primeiro mentor faleceu durante a década de 1970, com 100 anos de idade, o que corrobora a ideia de que já estivesse aqui há mais tempo. Também nesse grupo se concentra o maior número de lideranças com sacerdotes atuantes na cidade de Maringá e a eles filiados; Mãe Nerê é mãe-de-santo de Mãe Clô, Mãe Luzia iniciou Mãe Joaninha e Pai Jorge de Xangô à Umbanda. Afora esses, apenas Pai 
Hermano, responsável pela iniciação de Pai Zezinho, possui um filho-de-santo também atuante chefe de terreiro.

Em poucos casos, os filhos-de-santo das lideranças religiosas do primeiro e segundo grupo desenvolveram o papel de sacerdote. Informação relevante, pois todas as lideranças religiosas do primeiro grupo afirmaram não terem substitutos para os seus trabalhos. Para esses sacerdotes, quando suas atividades cessarem é provável que, naquele endereço, não sejam mais desempenhadas as funções de um terreiro. Embora alguns desses chefes tenham formado diversos filhos-de-santo, seus filhos biológicos, quando é o caso, não apresentariam desejo de atuarem como médiuns.

Tal constatação inviabiliza a permanência daquele espaço como local de prática religiosa. Digo isso porque, no único momento em que a liderança foi resultado de hereditariedade, o espaço de culto permaneceu o mesmo, como é o caso de Mãe Marilza, que recebeu a responsabilidade de manter a Tenda de Umbanda Nossa Senhora Aparecida de seus pais, Geraldo e Oscarina. Quando a hereditariedade não é observada, o espaço que antes era de atividade religiosa torna-se secular, como a antiga residência de Seu Álvaro e Dona Neuza, atuantes na cidade desde 1973 e que, ao ter seu dirigente falecido e Dona Neuza se aposentado dos serviços religiosos, tiveram o local transformado em uma residência comum pelo filho do casal.

Fenômeno que acrescenta à discussão sobre como as religiões afro-brasileiras se organizam em Maringá. E difere, por exemplo, da região de Salvador, na qual a substituição de uma liderança religiosa pode ser motivo de disputa entre os membros do terreiro, sobretudo quando se trata de um templo tradicional, conhecido (PARÉS, 2007).

Nesse sentido, surpreende saber que apesar do Terreiro de São Jorge, de Mãe Mocagi, receber mais de duzentos visitantes em suas festas, sua chefa religiosa não consiga encontrar um segundo responsável pelo lugar. Com isso, os terreiros costumam possuir o mesmo tempo de duração de seus fundadores. 
Tabela 3. Segundo Grupo de Lideranças Religiosas

\begin{tabular}{|l|}
\hline \multicolumn{1}{|c|}{ Décadas de 1970 a $1990^{10}$} \\
\hline Pai Armando \\
Mãe Clô \\
Dona Dirce \\
Mãe Elisa \\
Mãe Francisca \\
Zelador Gian \\
Pai Hermano \\
Mãe Joaninha \\
Mãe Lourdes \\
Mãe Marilza \\
Mestre Pedro \\
Dona Sirene \\
Dona Selma \\
Seu Turíbio Teodoro e Dona Ivany Leid \\
Pai Zezinho \\
Mãe Inajá \\
Mãe Neuza
\end{tabular}

Fonte: Giovane M. Gonzaga, 2017.

Esse grupo está caracterizado por se estabelecer em um período de intenso desenvolvimento demográfico do município de Maringá. Sobretudo entre os anos 1970 e 1980, quando a cidade recebeu migrantes de diversas regiões do país. Além disso, Prandi (2003) assinala esse período como característico para a expansão das religiões afrobrasileiras no país. Oro (1998) e Frigério (1999) indicam o período de crescimento internacional desses cultos, em que a Umbanda e o Candomblé, por exemplo, apresentariam templos distribuídos na América Latina, com destaque para a Argentina, e no mundo, onde a Alemanha curiosamente apresentara maior efervescência. Para as crenças afro-brasileiras, esse foi o momento de maior estabelecimento de lideranças religiosas. Para chefes de terreiro vindos de outros locais, além da região nordeste, notei a presença de líderes espirituais nascidos na região sul e sudeste do Brasil, no caso, São Paulo, Minas Gerais e Paraná.

\footnotetext{
${ }^{10}$ Em ordem cronológica: Dona Sirene (1970), Dona Dirce (1972), Mãe Neuza e Seu Álvaro (início dos anos 70), Pai Hermano (1972), Mãe Elisa (1973), Pai Zezinho (1974), Pai Armando (1975), Mãe Marilza (1975), Mãe Lourdes (1978), Seu Turíbio Teodoro e Dona Ivany Leid (1979), Mãe Clô (1982), Dona Selma (1983), Zelador Gian (1989), Mãe Joaninha (início de 80) Mestre Pedro (início de 80), Mãe Inajá (período estimado a partir de outras lideranças).
} 
Entretanto, é de se notar que o segundo grupo se caracterize por apresentar maior número de lideranças religiosas nascidas e criadas em Maringá. Dos líderes consultados: Pai Armando, Pai Hermano e Mestre Pedro são oriundos da região nordeste; Mãe Elisa, Mãe Francisca e Mãe Lourdes, das regiões Sul e Sudeste, enquanto outros nove são naturais do município maringaense. Nascidos em meados dos anos 1950, oito foram iniciados por um pai ou mãe-de-santo da cidade.

Tabela 4. Responsáveis por iniciar as Lideranças do Segundo Grupo

\begin{tabular}{|c|c|}
\hline Liderança religiosa & Responsável por sua iniciação \\
\hline Mãe Clô & Mãe Nerê \\
\hline Mãe Elisa & Mãe Sandra* \\
\hline Zelador Gian & Dona Izabel* + Dona Adelaide* \\
\hline Mãe Joaninha & Mãe Luzia \\
\hline Mãe Marilza & Dona Elizabeth (não encontrada) \\
\hline Dona Selma & Pai Hermano \\
\hline Pai Zezinho & Seus avós* \\
\hline Dona Sirene &
\end{tabular}

* Lideranças já falecidas. Fonte Giovane M. Gonzaga, 2017.

Torna-se esse o grupo com maior número de lideranças que tiveram sua iniciação em Maringá. É também provável que esse período seja o de maior atividade dos terreiros. Tal entendimento decorre do fato de que, com o tempo, os chefes de terreiro deixaram de realizar cerimônias religiosas públicas e passaram a atender individualmente.

O motivo, mais comentado por essas lideranças, para abandonarem atividades religiosas públicas, reside em problemas de saúde e o cansaço da idade. Entre todos também foi enfatizada a sensação de dever cumprido, pois o processo de assumir o papel de liderança religiosa, além de trabalhoso, por vezes não é assumido sem resistência anterior do próprio futuro-sacerdote, sendo compreensível que, com o tempo, sintam a vocação de líder religioso merecedora de uma aposentadoria. Os pais e mães-de-santo, em sua maioria, afirmaram não ter escolhido essa vida, mas necessitado dela (por exemplo, sofriam de alguma moléstia física ou psicológica curada apenas quando começaram suas iniciações em algum terreiro). 
Tabela 5. Terceiro Grupo de Lideranças Religiosas ${ }^{11}$

\begin{tabular}{|l|}
\hline Décadas de 2000 a 2010 \\
\hline Dona Glória Coutinho \\
Mãe Glória \\
Pai José \\
Pai Josias \\
Seu Osmar \\
Dona Rosiane \\
Dona Ruth \\
Dona Natália \\
Beto de Ogum \\
Deusa do Amor \\
\hline
\end{tabular}

Fonte: Giovane M. Gonzaga, 2017.

O terceiro grupo de lideranças religiosas é composto por espaços estabelecidos nas duas últimas décadas. Dessas pessoas, apenas Dona Rosiane, teve sua iniciação realizada em Maringá, conduzida por Pai Jorge Omolokô, que já se mudou de cidade. Por sua vez, Dona Natália é a única de origem nordestina, sendo os outros membros todos advindos do Sul e Sudeste do Brasil, principalmente do estado do Paraná. A vinda para o município possui motivos diferentes, desde pessoas que moravam em cidades menores, como Pai José e Dona Ruth, que afirmam tê-lo feito pelas oportunidades que um município maior proporcionaria, até aquelas que moravam próximas a grandes centros e se mudaram à procura de uma vida mais calma.

A forma de prática religiosa do terceiro grupo é a mais diversificada: vidência, Umbanda, benzimentos e Tambor de Mina, e apenas três dos dez locais mapeados, realizam cerimônias públicas. A maioria se reserva aos atendimentos particulares. Entretanto, é necessário salientar certa imprecisão das informações desse grupo, visto que três delas, Dona Natália, Beto de Ogum e Deusa do Amor, preferiram não participar da pesquisa, limitando nosso contato a conversas telefônicas. Outras duas, Pai Josias e Pai José, se mudaram de cidade, nos deixando apenas com uma visita curta, feita para a apresentação do projeto.

\footnotetext{
${ }^{11}$ Dona Ruth (entre finais dos anos 90 e 2000), Mãe Glória (2002), Seu Osmar (2002), Pai José (meados dos anos 2000), Dona Natália (2009) Pai Josias (2013), Dona Glória Coutinho (2014), Dona Rosiane (início da década de 10), Beto de Ogum (período estimado a partir de outras lideranças), Deusa do Amor (período estimado a partir do surgimento de anúncios de serviços religiosos em jornais).
} 
Esse decréscimo de novos terreiros estabelecidos na cidade nos últimos 20 anos contrasta com ideia de que, a partir do século XXI, houve um maior espaço para a prática religiosa afro-brasileira. Um movimento que, como destaca Prandi (2003), possui ligações com a expansão das igrejas neopentecostais e a perseguição religiosa aos cultos de matriz africana de que se utilizam. Traz como exemplo a fala de Anthony Garotinho, à época representante político da população evangélica, que concorria à presidência do Brasil em 2002. Para o candidato, a religião afro-brasileira constaria entre as três maldições de que o país sofreria. Se no segundo grupo, percebemos 17 templos fundados no município, o terceiro grupo se resume a dez novos lugares, dois deles já inexistentes. Pese as considerações de Prandi, os relatos de assédio moral de lideranças religiosas proveniente de membros da comunidade evangélica, faz sentido estabelecer uma relação entre a diminuição da atividade religiosa com matrizes africanas e a ascensão das religiões neopentecostais.

\section{O espaço da memória e o espaço das crenças}

Diante desse quadro, busca-se elencar algumas possibilidades de explicação, situadas na história de formação do espaço urbano maringaense e de como as personagens que compunham esse cenário foram pensadas pela produção bibliográfica relacionada à região. Para tanto, partirei das análises de Z. Rosendhal (1999) e Y. Tuan (1983) como bases para as correspondências entre a cidade, a forma como seu passado é construído e a formação dos aspectos religiosos e culturais. Ao abordar a figura do pioneiro e suas características étnico-culturais idealizadas, encontro apoio nas reflexões de Gonçalves (1995) e Fernandes (2014).

A relação entre espaço e religião constitui-se em elemento inseparável na história de fundação já das primeiras cidades. Segundo Rosendahl, no mundo moderno ocidental, as cidades se estruturaram sob uma forma triangular manifestada pelo poder do povo, da Igreja e do Estado (ROSENDAHL, 2008). A autora compreende que a relação entre espaço e sagrado é expressa na forma e função de como determinados lugares e prédios são construídos. A forma seria uma categoria geográfica fundamental de como as pessoas imprimem seus valores e crenças na arquitetura, assim como a função desempenhada por aquele local. O lugar sagrado se exprime por atributos qualificativos a partir da 
manifestação do sagrado em um determinado local, investindo esse espaço de lógicas funcionais e espaciais próprias (ROSENDAHL, 2008).

No caso da influência da religião sobre os espaços geográficos, Rosendahl entende que a exposição da fé no tempo e no espaço, modifica consideravelmente a paisagem de uma cidade, não se limitando apenas às características visíveis, mas se estendendo também à experiência da fé fornecida por meio de símbolos e mensagens. A compreensão da realidade socioespacial deve ser observada enquanto construção e atribuição de significados (ROSENDAHL, 2008).

A partir de tais referências, questiono em que medida os escritos memorialistas foram influenciados pela organização espacial da cidade, ou quais símbolos religiosos tiveram participação na formação da personalidade de um lugar, como o caso da Catedral Metropolitana Nossa Senhora da Glória, cartão-postal de Maringá e localizada na região central, construída de modo a ser vista de todos os lados da cidade. Essas estruturas simbólicas funcionariam como uma narrativa, tendo como preposição a condução dos fiéis a participar do espaço sagrado (ROSENDHAL, 1999), além de exercerem poder de ordenação da realidade, fundando uma referência do crível (CERTEAU, 1996).

Essa credibilidade tratar-se-ia de aspecto fundamental para o posicionamento de determinados aspectos culturais no centro do mundo de um indivíduo (TUAN, 1983). Centralidade cuja manutenção se situa em práticas que remontam a um passado glorioso, reforçando as relações entre disposições espaciais e cultura. O espaço urbano está repleto de locais onde seus ancestrais são cultuados silenciosamente (TUAN, 1983). Os nomes das ruas, edifícios públicos, conjuntos residenciais levam, em seus títulos, homenagens a personagens do passado maringaense, o que também implica em uma escolha das pessoas da cidade a serem lembradas.

Segundo J. Gonçalves, até o final do século XX, não se observava, entre os estudos científicos, concorrência para a configuração de um perfil desses antepassados, encontrando no pioneiro, sobretudo paulista e descendente de europeus, os significados socialmente compartilhados a respeito do passado maringaense. Sobre a historiografia regional norte paranaense, a presença dessa personagem seria um dos traços mais característicos. Mecanismo operado senão por recortes étnicos nessas pesquisas (GONÇALVES, 1995). 
Os signos do passado escolhidos para serem lembrados se materializam em lugares concretos; a igreja, o paço municipal, as ruas e avenidas contam aos olhos verdades que a cidade quer defender. Todavia, homenagear figuras pioneiras e personagens políticas de destaque é fenômeno que não demonstra ligação direta com o espaço ocupado pelas crenças afro-brasileiras na cidade. As aproximações podem ocorrer quando o olhar se volta para as personagens que antagonizariam o processo de constituição dessa região.

A figura idealizada dos pioneiros contrasta com todo um conjunto de categorizações sociais negativas, voltadas contra as figurações de grileiros, aventureiros de todos os matizes, vagabundos, [...] caboclos, indígenas [...]. Todos esses categoremas aparecem, via de regra, como negatividades absolutas [...] eles não costumariam valorizar nem as virtudes da propriedade, nem o vigor sacrossanto do trabalho árduo destinado a amealhar recursos para compra de novas terras. (GONÇALVES, 1995, p. 08)

Por meio de visita de campo, observamos que a maior parte das lideranças religiosas afro-brasileiras em Maringá provém da região Nordeste do Brasil ou, em última hipótese, seus pais são oriundos dessa parte do país sendo que, na década de 1970, período de maior fluxo migratório para a região, os migrantes nordestinos compunham 109.279 pessoas da população total do norte do Paraná. Em Maringá, a essa época, o número de habitantes oriundos do nordeste do Brasil somaria 9,6\% da população da cidade, compondo em números 7.661 moradores (FERNANDES, 2014).

Apesar de representarem uma parcela considerável da sociedade maringaense, relatos, produções memorialistas e pesquisas científicas da época demonstram a péssima recepção aos nordestinos na cidade, aos quais "fora relegado papel secundário por uma historiografia estabelecida, que propagou um discurso elitista e assimilado por veículos de comunicação" (FERNANDES, 2014, p. 61).

Assim como ressaltado com relação aos entrevistados para os números do IBGE, acerca da prática religiosa afro-brasileira, Fernandes afirma ter sido comum, os migrantes ocultarem suas raízes nordestinas. A ponto de aqueles que possuíam pele mais clara e rosto afilado preferirem, como forma de evitar o preconceito, a identidade de paulistas ou mineiros (FERNANDES, 2014). Tal prática de camuflagem funcionaria como esquiva a 
estereótipos subjugantes para com esses migrantes. Era dito que os nordestinos prezavam pouco pela higiene, possuíam ânimos aflorados, cometendo violências por quaisquer banalidades, possuíam intelecto inferior e eram preguiçosos, dentre outras características pejorativas.

Nesse contexto é que foi criado o mito da ocupação pioneira do norte do Paraná, no qual os pioneiros europeus e paulistas formaram a estrutura humana básica para que o projeto de desenvolvimento dessa região fosse profícuo (GONÇALVES, 1995). Mencionei acima que boa parte das lideranças religiosas afro-brasileiras em Maringá é oriunda do nordeste do Brasil ou descende de migrantes dessa região. Penso que tal dado, somado aos estudos de Gonçalves (1995) e Fernandes (2014), corrobora a leitura da camuflagem enquanto prática recorrente entre as pessoas que se sentissem pressionadas devido às suas práticas culturais. Caso dos adeptos e lideranças religiosas no município maringaense.

A aura de mistério que cerca as manifestações afro-brasileiras e a ideia de que são práticas ocultas, porque sigilosas, partilham do fundamento de algumas religiões. No Candomblé, por exemplo, certos rituais não são abertos ao público, bem como a feitura de determinados ebós e feitiços não são um saber compartilhado livremente. No entanto, procuramos refletir que tal aura mística está, muitas vezes, relacionada com a necessidade de não praticar publicamente de alguma religião afro-brasileira devido ao assédio social. Nas próximas páginas, apresento dados colhidos em campo e que permitem, embora timidamente, pensar sobre o processo de iniciação das lideranças; a relação com outros sacerdotes e; a identificação de seus templos.

\section{a) Primeiras manifestações de mediunidade e iniciação}

As pesquisas de campo e questionários revelam diferentes narrativas que descrevem as motivações para as lideranças à prática da religiosidade afro-brasileira. No entanto, dois tipos de situações chamaram atenção em função de sua recorrência. $O$ acometimento por uma enfermidade, sem sucesso com tratamento médico, que fora curada apenas por intervenção de um sacerdote (pai-de-santo, mãe-de-santo, benzedeira, por exemplo) e a transmissão hereditária da prática religiosa, na qual pais ou avós também possuíam mediunidade desenvolvida. 
Tais processos contradizem algumas suposições do senso comum, que geralmente atribuem a adesão a essas crenças por poder, dinheiro ou mesmo para prejudicar outras pessoas (BERKENBROK, 1997). No entanto, quando o sacerdócio não é manifestação de uma hereditariedade, como nos casos em que a iniciação acontecera para sanar problemas de saúde, as religiões afro-brasileiras foram um recurso evitado ao máximo, o que talvez se deva à imagem social negativa que lhes é imputada. Influente inclusive em pessoas criadas por pais praticantes, como é narrado por Mãe Marilza (2015), filha de uma das mais antigas mães-de-santo da cidade. Embora tenha sido criada por pai e mãe umbandistas - inclusive acompanhando o processo de desenvolvimento mediúnico da mãe -, até os acontecimentos que marcaram sua iniciação, não acreditava que manifestações religiosas de incorporação fossem verdadeiras. Para ela, mesmo tendo noção das práticas de seus pais, os médiuns enganavam as pessoas que os procuravam.

Mãe Marilza (2015) esclarece que estava destinada a se tornar mãe-de-santo, porque àquela época sequer acompanhava os rituais religiosos no barracão que sediava o templo, preferindo ficar em sua casa. No entanto, em um dia de Candomblé, ela conta que foi dormir e acordou agachada, entre os médiuns que incorporavam, com o corpo suado e as roupas sujas. Entrou em uma espécie de transe sonâmbulo, incorporou e caminhou até onde estava acontecendo a cerimônia religiosa, conforme relatou. Após o episódio, outros similares aconteceriam até que seguiu o conselho dos pais, de que só conseguiria controlar suas incorporações se fosse ritualmente iniciada na religião umbandista.

Ao contrário de Mãe Marilza, Pai Jorge de Xangô começara na infância a desempenhar a função de cambone ${ }^{12}$, para as entidades incorporadas por sua mãe. Médium iniciado por Dona Luzia, fora desejo seu, dar início aos ritos religiosos de iniciação. Como forma de reforçar essa decisão, Pai Jorge explica que não havia como negar ser um filho-de-santo de Xangô, visto que, sem nenhuma correspondência hereditária conhecida, nascera com os cabelos avermelhados, cor símbolo daquele orixá.

\footnotetext{
12 Um assistente para as entidades incorporadas. Durante as giras, o cambone fica responsável por trazer os objetivos relativos àquela divindade. O cachimbo preferido de um preto-velho, o uísque de um exu, o champanhe da pomba-gira, roupas características, entre outros.
} 
Com relação à idade, as lideranças religiosas relatam serem a infância ou a adolescência, os marcos do processo de iniciação; Mãe Marilza estava com quase 15 anos de idade e Pai Jorge com 12. É importante ressaltar que essa é uma característica geral dos relatos recolhidos na pesquisa de campo. Mestre Pedro (2016) ${ }^{13}$ narra que aos sete anos de idade já recebia instruções de seu avô sobre exercícios de adivinhação, além de prestar obrigações espirituais. O mesmo ocorrera com Dona Sirene $(2014)^{14}$, que teve sua infância marcada por brincadeiras de “duvinhá” (adivinhar) estimuladas pelos avós.

Para a maioria dos representantes, o começo da prática de alguma forma de religiosidade afro-brasileira se daria antes de completarem a idade de 20 anos, o que não é estranho, se comparado com a literatura acadêmica. A idade não seria fator determinante para ocupar uma posição hierárquica. Reis, em sua pesquisa, apresenta registros policiais de Antônio, escravo, líder de terreiro onde "apesar de ser moço, [ele exigia] que lhe tomassem a benção, e lhe prestassem obediência, inda mais os mais velhos" (REIS, 2008, p. 69).

Ao utilizar exemplos de tempos anteriores à abolição para pensar os finais do século XX, autores como Parés e Maggie analisam o momento de iniciação nos terreiros. Constatam o mesmo fundamento: não existe uma regra geral para a idade dos iniciados, pois quem determina isso é o sacerdote responsável por conduzir o rito de iniciação. Parés, ao narrar sobre as turmas de filhos-de-santo formadas no terreiro Seja Hundé, de Salvador, registra Vivi Agué Aboro, que deu início à sua formação mediúnica com idade entre nove e 10 anos. $E$ também uma filha de Abalhe, liderança do templo à época, que cumprira os primeiros ritos iniciáticos sem completar um ano de idade (PARÉS, 2007). Caputo (2012) relata que, no Candomblé, muitas vezes as crianças que se tornaram sacerdotes são esperadas e preparadas já durantes os primeiros meses de gestação. Ao pesquisar as relações entre os membros da Tenda Espírita Caboclo Serra Negra, Maggie descreve que Pedro, pai-de-santo, iniciara-se na macumba aos 13 anos de idade, e Sônia, segunda mãe-pequena, aos 17 (MAGGIE, 2001).

\footnotetext{
${ }^{13}$ As informações sobre Mestre Pedro foram produzidas a partir de visitas de campo, realizadas ao longo de seis anos de convívio com sua associação de capoeira e cultura negra, a ACCAMÊ.

${ }^{14}$ As informações sobre Dona Sirene foram produzidas a partir de visita de campo ao seu espaço de atendimento particular. Realizada no dia 01/07/2014.
} 
O chamado para a iniciação pode acontecer de diversas maneiras. Nina Rodrigues apresenta a história de uma neófita que, ao encontrar uma pedra de formato peculiar na rua, Ihe é revelado por sua mãe-de-santo qual seria a divindade que a moça deveria cultuar (RODRIGUES, 2006). Em outro exemplo, Ortiz narra que, às vezes, uma pessoa ao visitar uma cerimônia de caráter religioso afro-brasileiro, “cai no santo", isto é, fica tomada por uma incorporação involuntária (ORTIZ, 1978), fenômeno tratado como sinal de proeminente vocação mediúnica.

Para Pai Zezinho (2016), tais ocorrências se manifestariam a partir dos seis anos de idade, com sintomas do que considera um chamado espiritual à mediunidade. Apesar de muito jovem, o médium não atribui hereditariedade ao seu desenvolvimento. Mesmo tendo uma avó benzedeira, afirma que a relação entre os dois era pequena, nunca o assunto da prática religiosa afro-brasileira fora abordado. Por não haver nascido em um ambiente familiar candomblecista, Pai Zezinho circulou por uma série de terreiros e sacerdotes. Ainda que tenha "feito sua cabeça" com Pai Hermano, o médium atribui sua prática religiosa à experiência que adquiriu com diferentes pessoas.

O exemplo de Pai Zezinho, de desenvolvimento mediúnico baseado em uma dinâmica de mobilidade, encontra correspondências em outros entrevistados, como Dona Dirce (2016), que afirma ter herdado, junto com sua irmã, a sensitividade da avó, mas que nunca recebera qualquer espécie de preparação de um sacerdote exclusivamente. Afirmou ter desenvolvido sua prática religiosa por meio de visitas a inúmeros terreiros, servindo como médium de incorporação, ou apenas assistindo às sessões e ouvindo suas lideranças. No entanto, Dona Dirce atribui seu conhecimento sobre religiosidade mediúnica, principalmente, à intimidade com suas entidades e um poder intuitivo que lhe é natural.

\section{b) O contato entre lideranças religiosas da cidade}

De acordo com a maior parte das respostas, a forma de conduzir os rituais religiosos e posturas no dia a dia do terreiro esbarra em questões pessoais que, muitas vezes, impedem que a prática religiosa em Maringá, por parte de suas lideranças, se torne uma experiência coletiva como, por exemplo, o tempo necessário para o 
desenvolvimento de um neófito ou a cobrança de serviços religiosos. Os motivos podem ser encontrados na formatação das religiões afro-brasileiras e sua prática. Embora tivessem obtido diferentes resultados em suas pesquisas, a literatura acadêmica de maior expressão no século $X^{15}$ é unânime em relatar a presença do caráter de filiação na formação de um novo sacerdote, ou seja, seria necessário que alguém ensinasse os principais ritos a um iniciado.

Conhecimento adquirido apenas depois de anos servindo a um terreiro como médium. Dessa forma, ao inaugurar um novo templo, o sacerdote traria consigo características da pessoa ou do lugar em que foi iniciado. Fundamentos que perpassariam por aspectos práticos mais complexos e variáveis, como a cor de roupa adequada aos dias devotados a determinada divindade ou mesmo a tolerância ao humor e conversas paralelas no momento de cerimônias religiosas. Talvez por esse motivo, é complicada a presença de um grande número de lideranças coordenando um mesmo espaço religioso. Obedecer aos princípios de um terreiro não diz respeito apenas à disciplina, mas é fundamental para a eficácia religiosa dessas manifestações. Com isso, muitos pais e mãesde-santo optam pela segurança de trabalharem apenas sozinhos, como forma de garantir que cada ritual religioso alcance o efeito desejado.

Mãe Glória de Agbê ${ }^{16}$, formada na cidade de Itatiba-SP, conduz uma Casa de Tambor de Mina, manifestação religiosa que, em diversos aspectos, difere do que é praticado no Candomblé ou na Umbanda, fator que coloca Mãe Glória em uma posição isolada dos demais terreiros maringaenses, visto que possui um panteão diversificado em relação à Umbanda ou Candomblé, por exemplo ${ }^{17}$.

Ainda que a religião umbandista seja a mais praticada na cidade, não impede que seus sacerdotes desempenhem posição mais reservada em relação aos outros terreiros, como relata Seu Armando $(2017)^{18}$, médium de um terreiro em Santo André-SP que, ao

\footnotetext{
15 Posso citar obras como: CARNEIRO, Edson. Candomblés da Bahia. Salvador: Editor Museu do Estado da Bahia, 1948; VALENTE, Waldemar. Sincretismo religioso afro-brasileiro. Companhia Editora Nacional, 1955 e ORTIZ, Renato. A morte branca do feiticeiro negro. Petrópolis (RJ): Vozes, 1978.

${ }^{16}$ As informações sobre Mãe Glória de Agbê foram produzidas a partir de visita de campo ao Terreiro de Mina Jeje e Nagô de lemanjá e Ogum. Realizada 16/12/2016, entre às 14h30 e 16h.

17 No Tambor de Mina são cultuados também os encantados, sendo que entre eles estão espíritos relacionados a animais, como as serpentes; o que não ocorre nos demais terreiros visitados.

${ }^{18}$ As informações sobre Seu Armando foram produzidas a partir de visitas de campo à Tenda de Umbanda
} 
chegar no município maringaense, em 1975, não se identificara com nenhum dos templos que conheceu. Necessitou receber autorização do terreiro em que se formara para que pudesse conduzir atividades religiosas em sua residência.

Uma situação curiosa de isolamento é relatada por Seu Terúbio (2014), médium mais antigo do Terreiro Pai João da Mata ${ }^{19}$, no qual certos procedimentos rituais presentes não foram observados em nenhum outro local, como a obrigatoriedade dos visitantes e médiuns vestirem branco para participar das cerimônias ${ }^{20}$ e a necessidade de cadastro com informações pessoais. Seu Terúbio também afirma que, por não cobrar dinheiro para a execução de serviços religiosos, o templo seria alvo de inimizade de outras lideranças em Maringá por orientar seus visitantes a não pagarem por tais serviços em nenhum lugar. Um sistema controlado de visitas somado a divergências sobre posturas práticas faria com que o terreiro não recebesse muitas visitas de outras lideranças.

Situação constante de contato é demonstrada por lideranças que trabalharam juntas por algum tempo e, quando abriram seus próprios espaços, mesmo assim visitam uma a outra como forma de reforçar a prática religiosa compartilhada. Casos como os de Mãe

Agnela e Mãe Elisa, formadas na Tenda de Umbanda Nossa Senhora Aparecida, e de Pai Jorge de Xangô e Mãe Joaninha, ambos filhos-de-santo iniciados na Tenda de Umbanda Yansã.

Além das relações de irmandade, de iniciados no mesmo local, há também aquelas baseadas em filiação, do pai-de-santo para o seu iniciado como, também, as participações conjuntas, formadas pela afinidade em dividir as mesmas práticas religiosas. Se a filiação por algumas vezes dificulta a comunicação entre terreiros, ao mesmo tempo observamos que sacerdotes formados em Maringá tendem a manter participação em seus terreiros de

Pai José de Angola. Realizadas em 25/09/2014, entre às 11h30 e 15h. E no dia 16/01/2017, entre às 08h e 09h.

19 As informações sobre o Terreiro Pai João da Mata foram produzidas a partir de visitas de campo. Realizadas com a companhia de Seu Terúbio e Dona Ivany, membros mais antigos do templo, no dia 21/05/2014 - uniformizar o formato das datas, entre às 20h e 20h30. E no dia 15/06/2014, entre às $16 \mathrm{~h}$ e $17 \mathrm{~h} 15$.

20 As informações sobre o Terreiro Pai João da Mata foram produzidas a partir de visitas de campo. Realizadas com a companhia de Seu Terúbio e Dona Ivany, membros mais antigos do templo, no dia 21/05/2014, entre às 20h e 20h30. E no dia 15/06/2014, entre às $16 \mathrm{~h}$ e $17 \mathrm{~h} 15$. 
origem. Nesse sentido, são traçadas relações semelhantes ao que é descrito por Parés (2007), quando aborda a história de terreiros do bairro do Bogum, atual Engenho Velho da Federação, na cidade de Salvador. O autor destaca que, do tradicional Terreiro do Bogum, saíram ao menos duas outras lideranças religiosas que formariam seus próprios templos e, apesar da saída, os eventos realizados por esses terreiros recebiam a participação de todos.

Em Maringá temos alguns exemplos semelhantes, como o caso de Pai Jorge de Xangô, sua mãe biológica, e Mãe Luzia, responsável pela iniciação dos dois primeiros. Embora Pai Jorge conduza seu próprio terreiro desde meados dos anos de 1970, o médium participa regularmente das atividades na Tenda de Umbanda Yasã, regida por Mãe Luzia. O mesmo se dava também com a mãe biológica de Pai Jorge, quando viva. Em reciprocidade, toda festa religiosa do Centro Espírita Pai Xangô conta com a visita de Mãe Luzia. Luzalê foi também quem iniciou Mãe Joaninha ${ }^{21}$, estabelecendo a mesma dinâmica de participação ocorrida entre ela e Pai Jorge de Xangô.

Essas separações, muitas vezes não decorrem de algum desacordo entre sacerdote e iniciado, mas dos próprios deslocamentos do local de residência dos médiuns, como ocorrera com Mãe Agnela e Mãe Oscarina, já falecida, fundadora da Tenda de Umbanda Nossa Senhora Aparecida. Formada por Oscarina, Mãe Agnela participara ativamente, durante anos, no terreiro de sua mãe-de-santo. Ao se mudar do Jardim Alvorada para as proximidades da Avenida Kakogawa, distante cerca de quatro quilômetros, teve liberdade para abrir seu próprio terreiro, o que não a impediu de continuar participando das cerimônias religiosas no espaço de Mãe Oscarina sempre que chamada.

Também existem relações entre terreiros, como acontece com Pai Hermano ${ }^{22}$, Mãe $\mathrm{Clô}^{23}$ e Pai Jorge de Xangô, motivadas por afinidade e pela própria prática religiosa. Embora não realize mais cerimônias coletivas em sua residência, Pai Hermano participa

\footnotetext{
${ }^{21}$ As informações sobre Mãe Joaninha foram produzidas a partir de visita de campo ao Centro Espírita Martim Pescador. Realizada no dia 13/08/2014, entre às $18 \mathrm{~h}$ e $19 \mathrm{~h} 40$.

${ }^{22}$ As informações sobre Pai Hermano foram produzidas a partir de visita de campo ao Terreiro Ilê Oyá. Realizada no dia 14/12 /2016, entre às 15 h30 e $17 \mathrm{~h}$.

${ }^{23}$ As informações sobre Mãe Clô, Alekandê de Oxóssi, foram produzidas a partir de visitas de campo à Tenda Espírita Caboclo Sete Flechas. Realizadas no dia 03/09/2016, entre às 14 h45 e 16h30. E no dia $13 / 12 / 2015$, entre às $20 h$ e 03 h30.
} 
sempre que é convidado dos eventos de outros locais, como na Tenda Espírita Caboclo Sete Flechas, de Mãe Clô e no terreiro de Pai Jorge de Xangô e vice-versa.

Essas duas lideranças foram as que mais se mostraram dispostas a falar de outros terreiros. Mãe Clô, inclusive, convida todas as lideranças religiosas com que tem contato, quando há festas em seu templo. Formada médium na cidade de Maringá por Mãe Nerê24, mantém visitas regulares à casa de sua mãe-de-santo, contatos que contribuem para a consolidação de uma memória coletiva das crenças afro-brasileiras na cidade, impedindo que o passado de determinado local se perca quando, por alguma razão, deixa de funcionar.

Também existiram parcerias e filiações que não resistiram ao tempo. Ao narrar a dissolução de um terreiro no Rio de Janeiro devido a desentendimentos internos, Maggie afirma que os motivos perpassam tanto as relações pessoais entre os filhos-de-santo, como problemas estruturais de legitimação das lideranças; o fato de um dos médiuns do terreiro se considerar mais forte do que o pai-de-santo da casa, caso em que seriam melhores seu conhecimento sobre a prática religiosa e o poder de suas entidades, por exemplo (MAGGIE, 2001).

Em Maringá foi possível identificar dois aspectos diferentes da dissolução de parcerias e distanciamento de filhos-de-santo e seus iniciadores. O primeiro diz respeito ao questionamento da capacidade mediúnica do pai ou mãe-de-santo, o que considero uma característica estrutural, pois parece se tratar de uma circunstância recorrente para as lideranças religiosas. Na visita à Tenda de Umbanda Nossa Senhora Aparecida ${ }^{25}$ em um dia de mesa branca, presenciei uma das entidades de Mãe Marilza, líder do terreiro por herança biológica, alertar aos presentes que, embora a médium-chefe fosse outra, Mãe Oscarina falecera há cerca de cinco anos, a capacidade espiritual das divindades permanecia a mesma. Mãe Marilza estabeleceu relações de força contra possíveis questionamentos que aventassem sua incapacidade de assumir à altura a liderança do terreiro.

\footnotetext{
${ }^{24}$ As informações sobre Mãe Nerê foram produzidas a partir de visita de campo ao Terreiro de lemanjá. Realizada no dia 01/02/2016, entre às $14 \mathrm{~h}$ e $15 \mathrm{~h}$.

${ }^{25}$ As informações sobre Mãe Marilza e a Tenda de Umbanda Nossa Senhora Aparecida foram produzidas a partir de visitas de campo a este espaço. Realizadas nos dias 24/06/2014, entre às 14h e 16h30; 07/03/2015, entre às $14 \mathrm{~h}$ e $16 \mathrm{~h} 30 ; 18 / 07 / 2015$, entre às 2oh e ooh15.
} 
Noutra situação, apresentamos relato de Dona Selma $(2017)^{26}$, atuante na cidade há 40 anos. A médium oferece os serviços religiosos de vidência e aconselhamento espiritual e narra que, em sua experiência, os principais casos de discriminação de prática religiosa afro-brasileira vieram de seus próprios consulentes. Dona Selma (2017) relata que é recorrente que sejam feitas acusações durante as consultas, como também perguntas, formuladas na tentativa de encontrar na vidente uma charlatã.

Retornando as dissoluções de parcerias religiosas e afastamento de filiações, Dona Selma (2017) também relata um caso; ao ter manifestado predisposição à mediunidade com 16 anos de idade, fora Mãe Elizabete (não localizada) que lhe ensinara os principais elementos rituais no contato com as entidades, indicando-lhe seu santo-de-cabeça e acompanhando suas primeiras incorporações. Em troca, ela era ativa no terreiro, dando consultas no espaço e participando das giras de incorporação. No entanto, o afastamento entre as duas partiria de posturas pessoais em relação à condução dos serviços religiosos prestados. Segundo Dona Selma, Mãe Elizabete cobraria quantias exorbitantes para o atendimento religioso e a resolução de problemas espirituais. Afastada de sua mãe-desanto, Dona Selma cobra apenas pelo material utilizado e a soma de 10 reais $(R \$ 10,00)$ por consulta.

O afastamento das filiações também pode ser apenas uma posição pessoal do médium, que prefere trabalhar sozinho, como nos relata Pai Zezinho (2015) ${ }^{27}$. Instalado próximo ao Contorno Norte, entre os municípios de Sarandi e Maringá, o pai-de-santo fora iniciado por Pai Hermano, no início dos anos 1980. Embora ainda mantenha relações de amizade com aquele que fez sua cabeça, que cuidou de sua iniciação mediúnica, Pai Zezinho prefere conduzir os rituais religiosos de sua casa apenas com seus filhos-desanto. Muito raramente convida uma liderança de fora ou visita outros terreiros.

Na história contada por Seu Terúbio, o Terreiro Pai João da Mata foi fundado no ano de 1979 por Isabel Ugeda Filho em parceria com Mãe Lourdes ${ }^{28}$. Divergências rituais

\footnotetext{
${ }^{26}$ As informações sobre Dona Selma foram produzidas a partir de visitas de campo a seu espaço de atendimento particular. Realizadas em 23/09/2016, entre às 09h30 e 10h15; 18/12/2016, entre às $17 \mathrm{~h} \mathrm{e} 17 \mathrm{~h} 15$; 07/01/2017, entre às $14 \mathrm{~h} 30$ e $14 \mathrm{~h} 45$.

27 As informações sobre Pai Zezinho foram produzidas a partir de visitas de campo ao "Demoagi Gunze Keamazi". Realizadas no dia 18/09/2014, entre às 09 h30 e 11h. E no dia 18/12/2015, entre às $15 \mathrm{~h}$ e $16 \mathrm{~h} 30$.

${ }^{28}$ As informações sobre Mãe Lourdes, lyá Sandiá, foram produzidas a partir de visitas de campo. Realizadas no dia 18/06/2014, entre às 15h e 15h30; 29/07/2014, entre às 09h30 e 11h20; 29/08/2014, entre às 17h30 e $18 \mathrm{~h}$.
} 
entre as duas fizeram com que a segunda formasse seu próprio terreiro, em funcionamento até 2015, no Jardim Alvorada. Ao observar a disposição espacial dos dois templos, para entender quais posturas rituais seriam essas, percebi que a casa de Mãe Lourdes $^{29}$ expressava intensa relação com a natureza, notada pela diversidade de plantas medicinais e de simbólica religiosa, em que a médium parece conservar maior relação com o Candomblé, enfatizando o culto aos orixás sobre divindades espirituais, como caboclos e pretos-velhos.

O Terreiro Pai João da Mata parece focar na prática umbandista; orixás não se manifestam ali, e a relação das divindades com a natureza no terreiro quase não é simbolizada com plantas rasteiras e árvores, mas por meio de objetos simbólicos, como um ramo, um tronco de árvore como banco, entre outros.

Este item se esforçou em traçar um pequeno panorama das relações entreterreiros em Maringá. Com base nele, compreendo a ideia de que, dentro dos templos e consultórios, as lideranças religiosas organizam suas práticas sob um peso social diminuído. O item seguinte busca pontuar algumas questões sobre como, do terreiro para fora, vem à tona certos mecanismos de camuflagem, discrição necessária ao bom convívio desses representantes em seus bairros.

\section{c) Terreiro da porta para dentro: o espaço sagrado, o espaço público e a fronteira}

Ao abordar a relação dos maringaenses com os praticantes das religiões afrobrasileiras, gostaria de pensar na forma como os moradores dos bairros, onde estão localizados os seus templos, convivem com esse espaço.

Nas visitas de campo, quando ainda não possuía os endereços exatos dos locais, a partir de algumas referências, chegava próximo ao templo e conseguia encontrá-los

\footnotetext{
${ }^{29}$ Maria de Lourdes de Nascimento (Mãe Lourdes ou lalorixá Sandyá) nasceu na cidade de Painço-MG, veio para o município maringaense ao final dos anos 70 , junto com seu primeiro marido. Havia terminado suas obrigações de iniciação como filha de santo havia menos de três anos. Os fundamentos religiosos foram aprendidos por Mãe Lourdes na cidade de Taboão da Serra-SP, onde morava antes de vir para a cidade de seu último endereço. Foi lá também que Ihe foram contados quais eram os santos de sua cabeça, Yansã e Oxum. Informaç̃̃es obtidas durante visita de campo em: 29/07/2014, entreàs 09h30 e 11h20. Veio a falecer no mês de julho de 2016, aos 70 anos de idade. No endereço do Ilê Axé Oyá não se realizam mais cerimônias religiosas afro-brasileiras. Mas é ainda a residência de familiares de Mãe Lourdes. As árvores e ervas de que a sacerdotisa tanto se orgulhava continuam plantadas, cheias de seu axé.
} 
pedindo informação para a vizinhança. Em apenas duas dessas visitas, quando questionadas sobre a existência de um espaço de prática religiosa afro-brasileira naquelas redondezas, as pessoas reagiram de maneira inusitada.

$\mathrm{Na}$ primeira vez, procurava pela casa de Mãe $\operatorname{Agnela}^{30}$, no bairro Parque das Grevíleas. Perguntei a uma família, que conversava na calçada, se por ali morava Dona Agnela, mas não reconheceram o nome. No entanto, quando falei que procurava por uma mãe-de-santo, todos souberam indicar o endereço. Enquanto agradecia a informação e me distanciava do grupo, uma das mulheres disse que 'Deus não morava no local' para o qual me dirigia. Também aconselhou não ser necessário o uso de "macumba" para a resolução de problemas.

A outra situação ocorreu em uma das visitas ao Terreiro de São Jorge, liderado por Mãe Mocagi ${ }^{31}$. Sabia apenas o nome da rua onde o templo estava estabelecido. Por isso, andei várias vezes pelo local até encontrar o endereço. Em uma dessas buscas, uma moradora, para quem pedi orientação, garantira que, morando ali há mais de vinte anos, nunca ouvira falar de um lugar assim. Fato que não chamaria atenção, se o Terreiro de São Jorge não estivesse, a apenas, cinco casas do local. Parece ingenuidade acreditar que um lugar onde semanalmente, há aproximadamente sessenta anos, ressoa o som de atabaques, não seja percebido pela vizinhança.

Em inúmeras vezes, durante a pesquisa de campo, deparei-me com olhares de estranhamento quando não praticantes eram indagados sobre o assunto. Na tentativa de compreender tais reações, busquei auxílio em Tuan, quando analisa o processo pelo qual o espaço torna-se lugar a partir de referências-base. Segundo o autor, essas referências são construídas historicamente, por meio de experiências do indivíduo e do ambiente onde se encontra (TUAN, 1983). Nas situações acima mencionadas, a negação do espaço de prática religiosa afro-brasileira, ou do caráter sagrado desses locais, remonta a uma imagem historicamente construída.

O preconceito sobre a religiosidade afro-brasileira transforma templos em espaços estranhos, mesmo ameaçadores, ainda que essas crenças acompanhem todo o passado

30 As informações sobre Mãe Agnela foram produzidas a partir de visitas de campo. Realizadas dia $11 / 09 / 2014$, entre às $16 \mathrm{~h} 30$ e $18 \mathrm{~h}$. E no dia 22/07/2015, entre às $16 \mathrm{~h}$ e $16 \mathrm{~h} 30$.

31 As informações sobre Mãe Mocagi foram produzidas a partir de visita de campo. Realizada dia 09/08/2014, entre às 14 h30 e 16h30. E no dia 03/07/2015, entre às $16 \mathrm{~h}$ e $16 \mathrm{~h} 30$. 
da cidade. Nesse processo, mecanismos de camuflagem são operados por meio de táticas (CERTEAU, 1994), por meio das quais o indivíduo encontraria formas de ultrapassar barreiras culturais institucionalmente impostas como, por exemplo, praticar uma religião proibida no passado e socialmente malvista nos dias de hoje.

Lembremo-nos da prática religiosa dos escravos africanos no Brasil, quando as imagens de santos católicos se tornaram símbolos referentes aos orixás. As imagens das fachadas dos templos de religiosidade afro-brasileira estabelecidos em Maringá refletem disposições similares. O espaço de fora das casas, sobretudo o que fica no campo de visão da rua, quase sempre se apresenta como uma residência comum.

Dessa forma, um terreiro de Umbanda, quando visto de seu exterior, se confunde com as casas da vizinhança. As descrições físicas dos locais mapeados indicam essa condição de camuflagem. Mais do que não se identificarem em suas fachadas, o espaço sagrado do terreiro, ou do altar particular, se funde à arquitetura da casa. Tanto que, para uma visita, mesmo no interior da residência, ter conhecimento de que ali atua uma liderança de religiosidade afro-brasileira, é uma opção do anfitrião.

Tais camuflagens, embora dificilmente se mantenham para vizinhos mais próximos, funcionam como forma de evitar que esses espaços se tornem pontos de referência. Cautela de quem procura não chamar atenção de pessoas alheias às práticas religiosas. Ou pior, que façam do terreiro e de sua liderança um alvo de ódio e fanatismo religioso. Um acordo tácito, no qual os templos não possuem apelo estético e os demais moradores fingem que o local não existe como tal. Tal ideia está em conformidade com os estudos de Mayol (1996) e sua análise dos processos de vivência cotidiana no conjunto habitacional de Croix-Rousse, na cidade de Lyon, França, em que a relação dos moradores entre si e com o bairro se dá, principalmente, sob aspectos da conveniência:

[A conveniência] Representa, no nível dos comportamentos, um compromisso pelo qual cada pessoa, renunciando à anarquia das pulsões individuais, contribui com sua cota para a vida coletiva, com o fito de retirar daí benefícios simbólicos necessariamente protelados. Por esse "preço a pagar" (saber "comportar-se", ser "conveniente"), o usurário se torna parceiro de um contrato social que ele se obriga a respeitar para que seja possível a vida cotidiana. (MAYOL, 1996, p. 39) 
Dessa forma, se apresentar como espaço de prática religiosa afro-brasileira não é ilegal a nenhuma das lideranças religiosas da cidade. Porém, é conveniente que não se faça dessa forma, a fim de evitar quaisquer contatos indesejáveis por transeuntes que identifiquem determinado local como um terreiro. Conveniência historicamente forçada, necessário dizer. Pois as crenças afro-brasileiras têm em seu passado pelo menos três séculos de perseguição institucionalizada.

Sob a escravidão, de maneira geral, o indivíduo que fosse pego cultuando seus deuses de África sofreria punições, muitas vezes, severas. Com a abolição, as práticas religiosas afro-brasileiras viveram criminalizadas por sete décadas. Pesquisadores do século XX, como Ortiz (1978) e Negrão (1996) reúnem relatos de invasões violentas por parte da polícia aos terreiros de cidades como São Paulo, Rio de Janeiro e Salvador. O passado de perseguição, mesmo com a descriminalização dessas crenças, leva a um comportamento de camuflagem como forma de proteção.

Durante as pesquisas de campo, a maior parte dos entrevistados alegara não haver um motivo específico para não identificarem seus locais de culto como tais, apenas não o fizeram ou, se por um tempo mantiveram alguma forma de identificação, o deixaram de fazer, possível sintoma dos fatores culturais não-visíveis e não-ditos, enquanto formalidades determinantes das práticas de habitar (MAYOL, 1996).

Todos esses locais geográficos são também locais culturais e na medida em que nos afastamos de nossos lugares de intimidade torna-se maior a sensação de não pertencimento (BHABHA, 2005). Dessa forma, a moradia torna-se um refúgio de liberdade, lugar em que se pode pôr em prática aquilo que, fora dela, seria enxergado como bizarro, ou mesmo ofensivo.

Por exemplo, o programa Tribuna da Massa, jornal do meio-dia transmitido por uma filial do SBT no estado do Paraná, transformou em espetáculo os despachos encontrados por moradores da região de Maringá32 . Sob a alegação de que assim estaria

\footnotetext{
32 O programa é transmitido em toda região metropolitana de Maringá, além de abranger cidades circunvizinhas em uma distância de até $150 \mathrm{~km}$ da emissora. Os jornais do meio-dia fazem parte de um dos horários nobres da programação televisiva. As reportagens podem ser encontradas online, na página do telejornal na rede social Facebook. Como nos seguintes endereços eletrônicos: https://www.facebook.com/ TribunaDaMassaTibagi/videos/735911166498160/, https://www.facebook.com/TribunaDaMassaTibagi/ videos/716072301815380/, https:/www.facebook.com/TribunaDaMassaTibagi/ videos/ 811399375616005/. Acesso em 30/11/2017, às 13 h41.
} 
desfazendo o mal que aqueles despachos causariam, pois, os feitiços sempre teriam como finalidade atingir alguém, o repórter destrói os objetos do ritual, enquanto faz piadas sobre aquilo que encontra (uma boneca vestida como bruxa, dinheiro, perfume, etc.), e orienta para que os espectadores não tentem fazer o mesmo, pois ele estaria preparado para lidar com macumba, tendo uma particular proteção de Deus.

Partindo do pressuposto de que são necessários pontos de referências seguros para perscrutarmos espaços públicos, questionamos de que outros lugares dispõem as lideranças religiosas afro-brasileiras senão o interior de suas próprias residências (TUAN, 1983). Compreendo o mecanismo de camuflagem dos templos de religião afro-brasileira na cidade como desdobramento de processos históricos conflituosos, como também representações maléficas e jocosas das crenças afro-brasileiras. Inclusive, a exposição pode partir de veículos midiáticos de grande circulação na cidade, reforçando a presença de uma conveniência forçada.

Não que um pai ou mãe-de-santo não possam caminhar pelas ruas de Maringá com tranquilidade, porém, para que isso ocorra sem constrangimentos, parece existir a necessidade de supressão do papel de liderança religiosa. Exemplo disso é o caso relatado por Silva (2014): por ocasião da Semana da Consciência Negra, é comum que as escolas se organizem para, de alguma forma, ampliar o debate sobre a data. Nesse caso, foi chamada uma ialorixá, Mãe Glória de Agbê, para que palestrasse a alunos do ensino fundamental e médio.

Parte da proposta da convidada era a de apresentar canções e ritmos de atabaque característico do Tambor de Mina. Entretanto, durante a demonstração, uma das alunas presentes alegara não estar se sentindo bem, sendo retirada do local. A palestra acontecera pela manhã, com outra marcada para o período da noite, que não se realizou, pois, o pai da aluna que se sentiu indisposta havia ligado no colégio ameaçando que, caso o evento não fosse cancelado, ele mesmo faria algo para que não ocorresse. Diante de tal postura, a direção da escola achou melhor suspender as atividades da Semana (SILVA, 2014).

A não identificação da maioria dos terreiros pode ser analisada como uma forma de camuflagem social contra um espaço público inviabilizado de se tornar um lugar, em 
decorrência de motivos já mencionados, conveniência forçada, ausência de lugares familiares para além da própria residência.

No decorrer do texto procurei apresentar, por meio de Rosendahl (2008) e Gonçalves (1996), a possibilidade de a arquitetura refletir disposições culturais e históricas de determinado espaço. Para Tuan, os espaços míticos são aqueles construídos de maneira que retomem a história fundante de determinado lugar, contando esse passado sob uma retórica triunfante. Existem códigos que não devem ser transgredidos nesses locais, variando das roupas permitidas à forma de se comportar e de falar, elementos que reatualizam a memória de que, no território para o qual esses prédios foram construídos, todos deveriam ter a mesma importância perante as decisões políticas e a lei (TUAN, 1983, p. 97). No entanto, a base para a fundação desses espaços míticos parte de referências sensoriais. Por meio delas, o autor informa que passamos a classificar hierarquicamente objetos e espaços:

O status social é designado "alto" ou "baixo" em lugar de "grande" e "pequeno". Deus mora no céu. Tanto no Antigo como no Novo Testamento, Deus foi às vezes identificado com o céu. [...]. Em arquitetura, os edifícios importantes são colocados sobre plataformas, e, quando existe a tecnologia necessária, tendem a ser os mais altos. [...] isto é talvez sempre verdadeiro: uma pirâmide ou uma coluna de triunfo alta impõe maior estima do que uma baixa. (TUAN, 1983, p. 43)

Além de alto e baixo, em uma variedade de culturas, encontramos o lado direito sendo considerado muito superior ao esquerdo. Enquanto o primeiro significaria poder sagrado, fonte do que é bom e legítimo, o lado esquerdo se identificaria com o profano, o maléfico e o temido.

Na história das religiões afro-brasileiras encontram-se exemplos dessas referências espaciais. No Brasil do século XIX e boa parte do XX, práticas religiosas mediúnicas de matriz africana eram classificadas como "baixo espiritismo", em oposição ao "alto espiritismo" europeu. Até os dias de hoje, as entidades espirituais são, na maioria dos templos, divididas em ramos de trabalho à esquerda ou à direita de um plano espiritual (MONTEIRO, 2009).

O próprio altar sugere uma relação hierárquica entre as entidades do templo. $\mathrm{Na}$ maior parte dos casos, Oxalá é sempre posicionado no local mais alto do agdá, 
normalmente acompanhado de Nossa Senhora Aparecida e, por vezes, também, de São Miguel Arcanjo. Quando existem imagens referentes a outros orixás ou santos, eles se encontram em parte superior às imagens das entidades espirituais que se aproximam simbolicamente dessas divindades maiores. Dessa forma, é comum a imagem de Oxóssi ou São Sebastião estar posicionada acima das representações de caboclos. Às imagens de Exu, normalmente é destinada a parte mais baixa do altar, por serem identificados como espíritos de pouca luz.

Também são suas as entradas dos terreiros, onde nas proximidades se constrói uma casinha para devoção. Durante a pesquisa, essa disposição se tornou uma das principais referências na identificação dos templos de outras áreas residenciais comuns. A casinha de Exu poderia ser facilmente tomada por outra utilidade, por isso não a consideramos uma forma de identificação. Um leigo dificilmente suspeitaria que fosse ali o espaço de uma entidade. Mais uma vez, a necessidade de reforçar o caráter de camuflagem adotado pela maior parte das lideranças religiosas afro-brasileiras em relação aos seus locais de culto.

Referências diretas a Exu33 poderiam despertar o pânico de pessoas que o assimilam ao diabo. Tal expressividade não ocorre nos terreiros pesquisados, pois mesmo uma pessoa que se desagradasse ao ver uma imagem da divindade, e soubesse que ali estava configurado um espaço dedicado a Exu, e não para uma construção comum da casa, dificilmente seria despertada alguma animosidade, pois pessoas associam, às mesmas paisagens, sentimentos, atitudes e humores diferentes (CLAVAL, 2001, p. 45). Dessa forma, encontrar com os olhos uma cruz faz um cristão, em qualquer situação, lembrar-se de sua espiritualidade, enquanto a mesma imagem, para um budista chinês, por exemplo, produzirá outros significados.

A camuflagem toma novas características, não se trata apenas de uma forma de esconderijo. Referências simbólicas às crenças afro-brasileiras pululam nas entradas de muitos terreiros; elas são visíveis, na forma da citada casinha de Exu, mas também em fileiras de espadas-de-são-jorge, na predominância da cor branca para as paredes e

\footnotetext{
33 Segundo P. Verger (1999), a casinha de Exu é, em terras africanas, representada por uma escultura fálica do tamanho do braço de um adulto. No Brasil, o espaço, dedicado a oferendas de proteção da casa, toma aspectos menos chamativos para a sociedade.
} 
estruturas de um templo. Imagens apreensíveis para quem procura por uma mãe-desanto, uma vidente ou uma benzedeira, mas invisíveis para aqueles que não sabem ler, ou não estão buscando, os indícios da presença da religiosidade afro-brasileira. O que sugere, portanto, que essa seja a condição para a prática religiosa afro-brasileira em Maringá. Devem se manifestar apenas no interior de seus espaços. A fronteira que demarca onde começa o terreiro e termina a cidade é a fachada do templo.

\section{Considerações finais}

Neste trabalho, apresentei as práticas de camuflagem enquanto chaves explicativas para a compreensão do espaço e representação das religiões e crenças afrobrasileiras no espaço da cidade. Procurei definir esse mecanismo, sobretudo, a partir do conceito de tática, de Michel de Certeau (1994). Segundo o autor, as instituições adotariam estratégias visando à normatização dos indivíduos em um modelo específico de comportamentos e ideias. Dessa forma, somos estimulados a viver com base nesses padrões. Sempre existiram posturas idealizadas para as mais diversas atividades humanas como se vestir, se portar em público, trabalhar, estudar ou praticar uma religião. Porém, sempre existiram também as táticas, golpes no cotidiano, maneiras que o indivíduo, sob a demanda das instituições, encontra desvios, outros percursos, que atendam a resolução de suas ansiedades e emergências, nem sempre em consonância com os modelos estabelecidos. A História seria movida, sub-repticiamente, por essa relação entre táticas e estratégias, cujos resultados podem ser percebidos no caráter híbrido da cultura.

Durante os trabalhos de campo, encontrei terreiros de diversas denominações religiosas e lideranças que atendiam apenas consultas individuais. Identificam-se tendas, centro-espíritas, cantinho de oração, entre outros abordados no decorrer da pesquisa. As práticas religiosas produzem, no entanto, uma série de semelhanças, um universo religioso permeia essas manifestações. Ao olhar para a variedade de práticas religiosas afro-brasileiras, emerge a ideia de legibilidade de um universo religioso. Novas propostas de pesquisas podem surgir, vinculadas, por exemplo, às histórias de vida, trajetória religiosa, elementos analisáveis por outras ferramentas metodológicas, enfim, oportunizar uma maior compreensão da historicidade desse universo, as diferenças e 
proximidades entre os chefes de terreiro. Espero que este trabalho contribua para o reconhecimento das crenças afro-brasileiras enquanto relevantes na história e cotidiano maringaense.

\section{Referências}

ALBERTI, Verena. Manual de história oral. Rio de Janeiro: FGV, 2004.

AMORIM,Cleyde. Religiõesafro-brasileirasnaregiãodeMaringá:diversidade e invisibilidade. In: SEMINÁRIO NACIONAL SOCIOLOGIA \& POLÍTICA, 1., 2009, Curitiba. Anais [...], Curitiba: UFPR, 2009. Disponível em_http://www.humanas.ufpr.br/site/ evento/SociologiaPolitica/GTs-ONLINE/GT8\%20online/EixoIV/religioes-afro-brasileirasAmorim.pdf. Acesso em: 10 dez. 2017.

BERNARD, H. Russel. Research methods in anthropology: qualitative and quantitative approaches. Lanham-Inglaterra: AltaMira Press, 2006.

BERKENBROCK, Volney. A experiência dos orixás: um estudo sobre a experiência religiosa no Candomblé. Petrópolis (RJ): Vozes, 1997.

BHABHA, Homi. O local da cultura. Belo Horizonte: Editora UFMG, 2005.

CAPUTO, Stela Guedes. Educação nos terreiros: e como a escola se relaciona com crianças de candomblé. Rio de Janeiro: Pallas, 2012.

CERTEAU, Michel de. A escrita da história. Rio de Janeiro: Forense Universitária, 1982.

CERTEAU, Michel de. A invenção do cotidiano: artes de fazer. Petrópolis: Editora Vozes, 1994.

CERTEAU, Michel de. GIARD, Luce. MAYOL, Pierre. A invenção do cotidiano 2: morar, cozinhar. Petrópolis: Editora Vozes, 1998.

CLAVAL, Paul. O papel da nova geografia cultural na compreensão da ação humana. In: CORRÊA, Roberto Lobato; ROSENDHAL, Zeny. (orgs). Matrizes da Geografia Cultural. Rio de Janeiro: Ed. UERJ, 2001. p.35-86. 
CLAVAL, Paul. A geografia cultural. Florianópolis: EDUSC, 1999.

CONDURU, Roberto. Das casas às roças: comunidades de candomblé no Rio de Janeiro desde o fim do século XIX. Topoí, Rio de Janeiro, v. 11, n. 21, p. 178-203, 2010.

FERNANDES, L. De norte a sul e do sul a outros destinos: a presença e mobilidade nordestina no município de Maringá. 2014. 206f. Dissertação (Mestrado em História) Programa de Pós-Graduação em História. Universidade Estadual de Maringá, Maringá, 2014.

FRIGÉRIO, Alejandro. El futuro de las migraciones mágicas en

Latinoamerica. Ciências Sociais e Religião, v. 1, n. 1, p. 51-88, 1999.

GINZBURG, Carlo. Mitos, emblemas, sinais: morfologia e história. São Paulo: Companhia das Letras, 1990.

GONÇALVES, José Henrique. Historiografia regional e ideologias: em torno de algumas corografias políticas do Norte Paranaense - 1930/1980. 1995. 264f. Dissertação (Mestrado em História do Brasil) - Curso de Pós-Graduação em História do Brasil, Universidade Federal do Paraná, Curitiba, 1995.

GONZAGA, Giovane M. Dona Dirce Aguiar. Espaço de consultas individuais. 2016. Trabalho de campo. (Mestrado em História) - Universidade Estadual de Maringá, Maringá (PR), 2016.

GONZAGA, Giovane M. Dona Fia. Cantinho de Oração Mãe Cambinda, Sr. Ogum, São Jorge Guerreiro e Maria Conga. 2014. Trabalho de campo. (Mestrado em História) Universidade Estadual de Maringá, Maringá (PR), 2014.

GONZAGA, Giovane M.. Dona Glória Coutinho. Residência de Glória Coutinho. 2016. Trabalho de campo. (Mestrado em História) - Universidade Estadual de Maringá, Maringá (PR), 2016.

GONZAGA, Giovane M. Dona Rosiane. Terreiro Mariabás. 2017. Trabalho de campo. (Mestrado em História) - Universidade Estadual de Maringá, Maringá (PR), 2017.

GONZAGA, Giovane M. Dona Selma. Espaço de consultas individuais. 2016. Trabalho de campo. (Mestrado em História) - Universidade Estadual de Maringá, Maringá (PR), 2016. 
GONZAGA, Giovane M. Dona Sirene. Espaço de consultas individuais. 2014. Trabalho de campo. (Mestrado em História) - Universidade Estadual de Maringá, Maringá (PR), 2014.

GONZAGA, Giovane M. Mãe Agnela. Centro de Umbanda Nossa Senhora Aparecida. 2014. Trabalho de campo. (Mestrado em História) - Universidade Estadual de Maringá, Maringá (PR), 2014.

GONZAGA, Giovane M. Mãe Agnela. Centro de Umbanda Nossa Senhora Aparecida. 2015. Trabalho de campo. (Mestrado em História) - Universidade Estadual de Maringá, Maringá (PR), 2015.

GONZAGA, Giovane M. Mãe Clô. Tenda Espírita Caboclo Sete Flechas. 2014. Trabalho de campo. (Mestrado em História) - Universidade Estadual de Maringá, Maringá (PR), 2014.

GONZAGA, Giovane M. Mãe Clô. Tenda Espírita Caboclo Sete Flechas. 2015. Trabalho de campo. (Mestrado em História) - Universidade Estadual de Maringá, Maringá (PR), 2015.

GONZAGA, Giovane M. Mãe Elisa Teixeira. Terreiro Francisco Xavier de Azevedo. 2016. Trabalho de campo. (Mestrado em História) - Universidade Estadual de Maringá, Maringá (PR), 2016.

GONZAGA, Giovane M. Mãe Francisca. Residência de Francisca Algarves. 2014. Trabalho de campo. (Mestrado em História) - Universidade Estadual de Maringá, Maringá (PR), 2014.

GONZAGA, Giovane M. Mãe Francisca. Residência de Francisca Algarves. 2015. Trabalho de campo. (Mestrado em História) - Universidade Estadual de Maringá, Maringá (PR), 2015.

GONZAGA, Giovane M. Mãe Glória Agbê Ominesi. Terreiro de Mina Jeje e Nagô de lemanjá e Ogum. 2016. Trabalho de campo. (Mestrado em História) - Universidade Estadual de Maringá, Maringá (PR), 2016.

GONZAGA, Giovane M. Mãe Joaninha. Centro Espírita Martim Pescador. 2014. Trabalho de campo. (Mestrado em História) - Universidade Estadual de Maringá, Maringá (PR), 2014.

GONZAGA, Giovane M. Mãe Joaninha. Centro Espírita Martim Pescador. 2015. Trabalho de campo. (Mestrado em História) - Universidade Estadual de Maringá, Maringá (PR), 2015. 
GONZAGA, Giovane M. Mãe Lourdes lyá Sandiá. Ilê Axé Oyá. 2014. Trabalho de campo. (Mestrado em História) - Universidade Estadual de Maringá, Maringá (PR), 2014.

GONZAGA, Giovane M. Mãe Luzia/ Luzalê. Tenda de Umbanda Yasã. 2014. Trabalho de campo. (Mestrado em História) - Universidade Estadual de Maringá, Maringá (PR), 2014.

GONZAGA, Giovane M. Mãe Luzia/ Luzalê. Tenda de Umbanda Yasã. 2015. Trabalho de campo. (Mestrado em História) - Universidade Estadual de Maringá, Maringá (PR), 2015.

GONZAGA, Giovane M. Mãe Marilza e Seu Francisco. Tenda de Umbanda Nossa Senhora Aparecida. 2014. Trabalho de campo. (Mestrado em História) - Universidade Estadual de Maringá, Maringá (PR), 2014

GONZAGA, Giovane M. Mãe Marilza e Seu Francisco. Tenda de Umbanda Nossa Senhora Aparecida. 2015. Trabalho de campo. (Mestrado em História) - Universidade Estadual de Maringá, Maringá (PR), /2015.

GONZAGA, Giovane M. Mãe Mocagi. Terreiro de São Jorge. 2014. Trabalho de campo. (Mestrado em História) - Universidade Estadual de Maringá, Maringá (PR), 2014.

GONZAGA, Giovane M. Mãe Mocagi Terreiro de São Jorge. 2015. Trabalho de campo. (Mestrado em História) - Universidade Estadual de Maringá, Maringá (PR), 2015.

GONZAGA, Giovane M. Mãe Nerê. Terreiro de lemanjá. 2016. Trabalho de campo. (Mestrado em História) - Universidade Estadual de Maringá, Maringá (PR), 2016.

GONZAGA, Giovane M. Mãe Onofra. Residência de Dona Onofra. 2016. Trabalho de campo. (Mestrado em História) - Universidade Estadual de Maringá, Maringá (PR), 2016.

GONZAGA, Giovane M. Mãe Onofra. Residência de Dona Onofra. 2017. Trabalho de campo. (Mestrado em História) - Universidade Estadual de Maringá, Maringá (PR), 2017.

GONZAGA, Giovane M. Mãe Ruth. Tenda de Umbanda Dr. José Pelintra. 2017. Trabalho de campo. (Mestrado em História) - Universidade Estadual de Maringá, Maringá (PR), 2017.

GONZAGA, Giovane M. Mestre Pedro. Terreiro de Pai Benedito - Senzala Nova - Casa de Dona Tê. 2017. Trabalho de campo. (Mestrado em História) - Universidade Estadual de Maringá, Maringá (PR), 2017. 
GONZAGA, Giovane M. Pai Agostinho. Centro de Umbanda Pai Ogum. 2017. Trabalho de campo. (Mestrado em História) - Universidade Estadual de Maringá, Maringá (PR), 2017.

GONZAGA, Giovane M. Pai Hermano. Terreiro llê Oyá. 2016. Trabalho de campo. (Mestrado em História) - Universidade Estadual de Maringá, Maringá (PR), 2016.

GONZAGA, Giovane M. Pai Jorge (Vila Esperança). Centro Espírita Pai Xangô. 2016. Trabalho de campo. (Mestrado em História) - Universidade Estadual de Maringá, Maringá (PR), 2016.

GONZAGA, Giovane M. Pai José/Nega Zé. Centro Espírita lemanjá. 2016. Trabalho de campo. (Mestrado em História) - Universidade Estadual de Maringá, Maringá (PR), 2016.

GONZAGA, Giovane M. Pai José/Nega Zé. Centro Espírita lemanjá. 2017. Trabalho de campo. (Mestrado em História) - Universidade Estadual de Maringá, Maringá (PR), 2017.

GONZAGA, Giovane M. Pai Josias. Centro Espírita Pai Xangô. 2014. Trabalho de campo. (Mestrado em História) - Universidade Estadual de Maringá, Maringá (PR), 2014.

GONZAGA, Giovane M. Pai Zezinho.Demoagi Gunze Keamazi. 2014. Trabalho de campo. (Mestrado em História) - Universidade Estadual de Maringá, Maringá (PR), 2014.

GONZAGA, Giovane M. Pai Zezinho. Demoagi Gunze Keamazi. 2016. Trabalho de campo. (Mestrado em História) - Universidade Estadual de Maringá, Maringá (PR), 2016.

GONZAGA, Giovane M. Seu Armando. Tenda de Umbanda Pai José de Angola. 2014. Trabalho de campo. (Mestrado em História) - Universidade Estadual de Maringá, Maringá (PR), 2014.

GONZAGA, Giovane M. Seu Armando. Tenda de Umbanda Pai José de Angola. 2017. Trabalho de campo. (Mestrado em História) - Universidade Estadual de Maringá, Maringá (PR), 2017.

GONZAGA, Giovane M. Seu Osmar. Espaço de consultas individuais. 2017. Trabalho de campo. (Mestrado em História) - Universidade Estadual de Maringá, Maringá (PR), 2017.

GONZAGA, Giovane M. Seu Turíbio Teodoro e Dona Ivany Leid. Terreiro Pai João da Mata. 2014. Trabalho de campo. (Mestrado em História) - Universidade Estadual de Maringá, Maringá (PR), 2014.

GONZAGA, Giovane M. Seu Turíbio Teodoro e Dona Ivany Leid. Terreiro Pai João da 
Mata. 2014. Trabalho de campo. (Mestrado em História) - Universidade Estadual de Maringá, Maringá (PR), 2014.

GONZAGA, Giovane M. Zelador Gian Roger. Terreiro Baiano Zé do Coco. 2016. Trabalho de campo. (Mestrado em História) - Universidade Estadual de Maringá, Maringá (PR), 2016.

GONZAGA, Giovane M. Zelador Gian Roger. Terreiro Baiano Zé do Coco. 2017. Trabalho de campo. (Mestrado em História) - Universidade Estadual de Maringá, Maringá (PR), 2017.

GONZAGA, Giovane Marrafon. Memórias, notícias e espaços: a presença das religiões afro-brasileiras em Maringá-PR (2000 - 2014). Dissertação (mestrado em História) Universidade Estadual de Maringá, Maringá, 2018, p.158.

MAGGIE, Yvonne. Guerra de orixás. Rio de Janeiro: Editora Zahar, 2001.

MAYOL, Pierre. Morar. In: CERTEAU, Michel de; GIARD, Luce; MAYOL, Pierre (orgs). A invenção do cotidiano 2: morar, cozinhar. Petrópolis: Editora Vozes, 1996.

MONTERO, Paula. Secularização e espaço público: a reinvenção do pluralismo religioso no Brasil. Revista etnográfica, Lisboa, v. 13, n.1, p.7-16, maio 2009.

NEGRÃO, Lísias. Entre a cruz e a encruzilhada. São Paulo: Edusp, 1993.

ORO, Ari. As religiões afro-brasileiras: religiões de exportação. In: AFROAMERICAN RELIGIONS IN TRANSITION. INTERNATIONAL CONFERENCE OF THE AMERICANISTS. Anais [....] Uppsala, Suécia: s.n., jul. 1998.

ORTIZ, Renato. A morte branca do feiticeiro negro. Petrópolis (RJ): Vozes, 1978.

PARÉS, Nicolau. A formação do candomblé: história e ritual da nação jeje na Bahia. 2. ed. Campinas: Editora da UNICAMP, 2007.

PRANDI, Reginaldo. As religiões afro-brasileiras e seus seguidores. Revista de Ciências Sociais, Porto Alegre, v. 3, n. 1, jun. 2003.

PORTELLI, Alessandro. A filosofia e os fatos: narração, interpretação e significado nas memórias e nas fontes orais. Revista Tempo, Rio de Janeiro, v. 1, n.2, p. 59-72, 1996. 
ORTIZ, Renato. A morte branca do feiticeiro negro. Petrópolis (RJ): Vozes, 1978.

REIS, João José. Domingos Sodré, um sacerdote africano. São Paulo: Companhia das Letras, 2008.

RODRIGUES, Raimundo Nina. O animismo fetichista dos negros baianos. Rio de Janeiro: Fundação Biblioteca Nacional: Editora UFRJ, 2006.

ROSENDHAL, Zeny. Hierópolis: o sagrado e o urbano. 1. ed. Rio de Janeiro: Ed. UERJ, 1999.

ROSENDHAL, Zeny. O sagrado e o urbano: gênese e função das cidades. Rio de Janeiro: Espaço e Cultura (UERJ), 2008.

SILVA, Eronildo José da. Maringá de todos os santos: presença das religiões afrobrasileiras. 2014. 307f. Tese (Doutorado em Ciências Sociais) - Programa de PósGraduação em Ciências Sociais, PUC/SP, São Paulo, 2014.

TUAN, Yi-Fu. Espaço e lugar: a perspectiva da experiência. São Paulo: Difel, 1983.

VERGER, Pierre. Notas sobre o culto aos orixás e voduns na Bahia de Todos os Santos, no Brasil, e na antiga costa dos escravos, na África. São Paulo: edUSP, 1999.

Recebido em 20/08/2018 Aprovado em 30/04/2019

Universidade do Estado de Santa Catarina - UDESC Programa de Pós-Graduação em História - PPGH Revista Tempo e Argumento Volume 11 - Número 28 - Ano 2019 tempoeargumento@gmail.com 


\section{ANEXO 1}

QUESTIONÁRIO APLICADO EM LIDERANÇAS RELIGIOSAS DE MARINGÁ, PR

PESQUISA: MAPEAMENTO GEOGRÁFICO DA PRESENÇA DE LIDERANÇAS RELIGIOSAS AFROBRASILEIRAS EM MARINGÁ - PR.

PESQUISA DE: Giovane M. Gonzaga

ORIENTADORA: Vanda Fortuna Serafim

ENTREVISTADO:

NOME DO TEMPLO/TERREIRO:

ENDEREÇO:

LINHA(S) DE ATUAÇÃO:

RESPONSÁVEL(IS) PELO TEMPLO:

DATA EM QUE FOI FUNDADO:

FUNCIONAMENTO:

( ) EM DIAS E HORÁRIOS PRÉ-DETERMINADOS;

( ) CONFORME APARECEM INTERESSADOS;

№ ESTIMADO DE COMPONENTES:

№ ESTIMADO DE FREQUENTADORES:

QUANDO E COMO A PRÁTICA RELIGIOSA AFRO-BRASILEIRA TEVE INÍCIO EM SUA VIDA?

QUANDO E COMO SE DEU O ESTABELECIMENTO NA CIDADE DE MARINGÁ-PR?

QUAL A RELAÇÃO DO ENTREVISTADO COM OUTRAS LIDERANÇAS RELIGIOSAS NA CIDADE?

JÁ SOFREU ALGUM TIPO DE PERSEGUIÇÃO POR CONTA DA PRÁTICA RELIGIOSA? PODE CONTAR SOBRE O OCORRIDO?

OBSERVAÇÕES ADICIONAIS: 